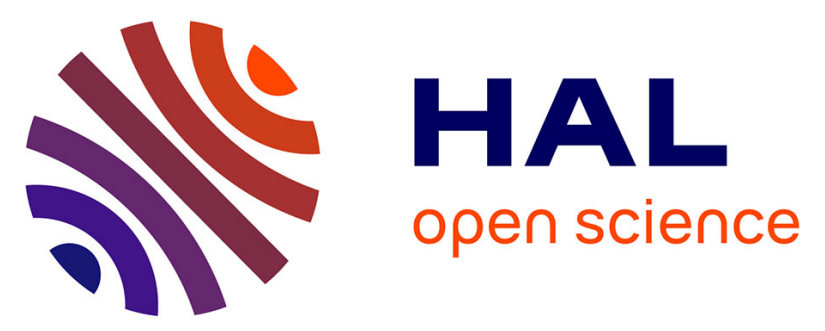

\title{
Contrasted Late Glacial and Holocene hydrology of Sarliève paleolake (France) from sediment geometry and detrital versus biochemical composition
}

Agathe Fourmont, Jean-Jacques Macaire, Jean-Gabriel Bréhéret

\section{- To cite this version:}

Agathe Fourmont, Jean-Jacques Macaire, Jean-Gabriel Bréhéret. Contrasted Late Glacial and Holocene hydrology of Sarliève paleolake (France) from sediment geometry and detrital versus biochemical composition. Journal of Paleolimnology, 2009, 41 (3), pp.471-490. 10.1007/s10933-008-9238-y . insu-00403897

\section{HAL Id: insu-00403897 https://hal-insu.archives-ouvertes.fr/insu-00403897}

Submitted on 8 Sep 2009

HAL is a multi-disciplinary open access archive for the deposit and dissemination of scientific research documents, whether they are published or not. The documents may come from teaching and research institutions in France or abroad, or from public or private research centers.
L'archive ouverte pluridisciplinaire HAL, est destinée au dépôt et à la diffusion de documents scientifiques de niveau recherche, publiés ou non, émanant des établissements d'enseignement et de recherche français ou étrangers, des laboratoires publics ou privés. 


\title{
Contrasted Late Glacial and Holocene hydrology of Sarliève paleolake (France) from sediment geometry and detrital versus biochemical composition
}

\author{
Agathe Fourmont $^{1}$, Jean-Jacques Macaire ${ }^{1}$ and Jean-Gabriel Bréhéret ${ }^{1}$ \\ (1) UMR CNRS 6113 ISTO-Tours, Laboratoire de Géologie des Environnements \\ Aquatiques Continentaux (GéEAC), Faculté des Sciences et Techniques, Université \\ François-Rabelais, Parc de Grandmont, F37200 Tours, France
}

\begin{abstract}
Since the end of the Last Glacial Maximum, hydrology in Europe has been influenced by both climate changes, and since Neolithic times, an increase in human activity. Paleohydrological reconstructions, especially from lake studies, can help identify the respective impact of these two factors. The present work focuses on a lacustrine geosystem, the Sarliève paleolake in the Massif Central (France), in an unusually dry, temperate area. The lake sediment geometry (core drillings, geotechnical methods), and the geochemical and mineralogical characterization of the catchment rocks and soils, and of the lacustrine deposits, indicate major variations in paleohydrology during the last 12,000 years as dated by ${ }^{14} \mathrm{C}$, palynology and tephrochronology. In addition, a model quantifying detrital versus biochemical lacustrine components was developed to identify hydrological trends. The data show that the Sarliève area was characterized mainly by remarkably dry conditions, hence sharpening the climatic trends at middle latitudes in Western Europe. Three main hydrological phases are distinguished since the Late Glacial: (1) 13.7-7.5 ka cal BP, a dominant dry climate, with a peak at ca. $8 \mathrm{ka}$ cal BP, leading to a lowstand in water level and unusual mineral authigenesis, zeolite then dolomite, constituting up to $60 \%$ of the lacustrine sediments; (2) 7.5 to ca. $5.3 \mathrm{ka}$ cal BP, repeated short-duration hydrological alternations that could have been climatedriven: lowstands in water level with up to $60 \%$ biochemical minerals versus higher water levels with $<10 \%$ biochemical minerals; (3) $5.3 \mathrm{ka}$ cal BP to the Middle Ages (i.e. beginning in the 5th century AD), a hydrological trend towards perennial high water level, with mainly detrital sediments, probably linked to climate evolution, except periods of obvious humandriven drying during the last two millennia.
\end{abstract}

Keywords Paleohydrology - Paleoclimate - Holocene - Lacustrine sediments - Human activity

\section{Introduction}

Watershed hydrology is governed by many factors: lithology, topography, climate, vegetation and human activities. Although present-day hydrological variables can be measured directly in rivers or lakes, paleohydrologic data are scarce and imprecise. Some variables can be reconstructed from water-table levels and sediment archives in wetlands (rivers, fens, bogs or lakes) (Aaby 1976; Gregory and Maizels 1991; Sunborg and Janson 1991; Barber et al. 1994; Magny 1998). Lakes are particularly favourable for such reconstructions owing to their high sedimentation rate. Water-table levels can be calculated by comparing altitudes of lake bottom, outlet level or shorelines (Digerfeldt 1986; Yu and Harrison 1995). Geometry and composition of sediments often provide accurate indications of water depth and quality (Håkanson and Jansson 1983; Anadon et al. 1991). Paleohydrological variations provide valuable information about paleoclimate changes in different environments (Harrison and 
Metcalfe 1985; Lezine and Casanova 1991; Magny 1992, 1998; Harrison et al. 1993), and also provide information on human activities (deforestation influencing runoff, erosion and evapotranspiration, drainage, etc.) in Europe since the Neolithic period (Dearing and Foster 1986; Zolitschka et al. 2003; Macaire et al. 2006). Numerous studies of lakes in temperate (Harrison and Digerfeldt 1993; Magny 1993, 2001, 2004), Mediterranean (Lamb et al. 1989; Harrison and Digerfeldt 1993; Détriché et al. 2008) and arid (Petit-Maire and Riser 1981; Servant and Servant 1983; Gasse et al. 1987) areas show that the magnitude of paleohydrological variations during the Late Glacial and the Holocene generally increased from high towards low latitudes, especially in closed lakes (Street-Perrott and Roberts 1983): arid areas are often characterized by a contrasted alternation of lake expansion and reduction periods, with occasional drying. The so-called "Marais de Sarliève" or Sarliève paleolake provides a good example of such a contrasted paleohydrology in a temperate area: the French Massif Central. Sarliève paleolake catchment is characterized by exceptionally low rainfall (microclimate) and the depression contains sediments showing unusual facies and minerals for such an area (Fourmont et al. 2006; Bréhéret et al. 2008). The Sarliève catchment was also affected by considerable human activity since the Neolithic (Trément et al. 2007). The purpose of this paper is to provide additional information on paleohydrological variations in this temperate

\section{Study site}

The "Marais de Sarliève" is an ancient lake, formed a little before $13.7 \mathrm{ka}$ cal BP (Fourmont et al. 2006), located $10 \mathrm{~km}$ southwest of Clermont-Ferrand in the Limagne rift (Fig. 1a). Some authors (Derruau 1949; Gachon 1963; Lenselink et al. 1990) consider that the lacustrine depression was formed by fluvial erosion and then closed by alluvial or colluvial deposits. However, the depression may have a tectonic origin, as suggested by Ballut (2000): our drillings show a bedrock threshold covered by mud-flow deposits of only one meter thickness at the outlet of the lake; faults bordering the depression on the west and northeast (Morange et al. 1971) could have been reactivated during the phase of volcanic activity that began during the Late Glacial (De Göer de Herve et al. 1991). The depression filled with sediments until it was drained by humans during the 17th century (Fournier 1996). The dry lake bed ( $X=663,780 \mathrm{~m} ; Y=2,082,180 \mathrm{~m}$ in the Lambert Conformal Conic system) has a surface area of about $5 \mathrm{~km}^{2}$ at an altitude of about $345 \mathrm{~m}$; it is bordered on the north and east by alluvial terraces (Lenselink et al. 1990). The catchment area $\left(29 \mathrm{~km}^{2}\right)$ is mainly composed of Oligocene marls and limestones, partly dolomitic and sometimes gypsum-rich, with small outcrops of basaltic rocks on the top of the surrounding hills up to $745 \mathrm{~m}$ (Jeambrun et al. 1973). Marly bedrock is highly impermeable, and the depression can only be drained by evaporation or via the outlet located at the north-eastern end of the catchment (Fig. 1b). Currently, the Sarliève catchment is located in an area characterized by a distinct continental microclimate: mean annual rainfall is $<600 \mathrm{~mm}$ (Fig. 1a), one of the lowest in France (Kessler and Chambraud 1986).

\section{Materials and methods}

Lacustrine sediments and catchment rocks and soils

Lacustrine sediments were studied from 31 core drillings (S1 to S30 + AUB) retrieved with a percussion sampler (Eijkelkamp), completing one core made by Gachon in 1963 and 5 large pit sections $(8 \mathrm{~m} \times 8 \mathrm{~m})$ (SP1 to SP4 and S177) carried out for archaeological surveys by the INRAP (Institut National de Recherches Archéologiques Préventives) (Fig. 2). Samples analyzed were collected in S2, S9, S10, S14, S17, S21 and S22 cores, and SP1, SP3 and SP4 pits. To determine the sediment geometry in the depression, 62 geotechnical tests (static penetrometry) (Fig. 2) carried out by the Fondasol-Auvergne society were analyzed: 
penetrometric data mainly distinguished gravelly-sandy bodies and "hard" substratum (resistance to penetration $>6 \mathrm{Mpa}$ ) from clayey-silty to silty-sandy sediments ( $<6 \mathrm{Mpa}$ ). In addition, results of geophysical prospection performed on the northern and southern parts of the marsh (Hinschberger et al. 2006) were used. To compare lacustrine sediment and catchment bedrock and soil compositions, 44 rocks and 53 soils were sampled in the catchment. Samples were collected in 51 different sites distributed spatially in six lithologic units (Fig. 3): 3 rock units (UR1 to UR3) and 3 soil units (US1 to US3). These units were determined on the basis of principal lithologic features from geological (Jeambrun et al. 1973) and pedological maps (Bornand et al. 1968): carbonate-rich marly rocks (UR1) and soils (US1), basaltic rocks (UR2) and soils (US2), and alluvial sediments (UR3) and soils (US3). Moreover, analyses of two basalts from the Gergovie plateau (Michel 1948; Jeambrun et al. 1973) and three terrace-alluvium samples (Lenselink et al. 1990) were used for further calculations (mean UR2 and UR3 compositions, respectively).

\section{Geochemical and mineralogical analyses of catchment rocks and soils, and lacustrine sediments}

Geochemical analyses were performed on all samples of bedrocks and soils and 69 samples of lacustrine sediments taken in S10, S14, S17, S21 and S22 cores, and SP3 and SP4 pits. Si, A1, total $\mathrm{Fe}, \mathrm{Mn}, \mathrm{Mg}, \mathrm{Ca}, \mathrm{Na}, \mathrm{K}, \mathrm{P}$, Ti oxide mass proportions were measured by ICP-AES on dried $\left(40^{\circ} \mathrm{C}\right)$ and finely powdered samples after lithium metaborate fusion and acid digestion. Total carbonate content was determined in all bedrock and soil samples and in 159 lacustrine sediment samples mainly collected in core S17, using the conventional calcimetry method. Bedrock, soil and sediment-forming minerals were determined on fine powdered bulk samples using XRD (Rigaku diffractometer, anticathode $\mathrm{Cu}$ ). Semi-quantitative data were obtained as a percentage by estimating the surface area of the most intense diffraction peak of each mineral. The proportion of different types of Ca-carbonates was obtained by calibrating the XRD data with the carbonate content estimated by calcimetry. Silicate content was calculated as the difference between $100 \%$ and the carbonate content in each sample. Nonclayey silicate and clay mineral contents were determined from silicate content and bulk XRD data, using the same method as for carbonates. Clay minerals were determined on the $<2 \mu \mathrm{m}$ fraction using XRD. Minerals of bedrocks and soils (20 samples) and sediments (60 samples) were observed using a scanning electron microscope (SEM LEO, Gemini, Zeiss DSM 982) coupled with an energy-dispersive spectrometer (EDS, Noran, Idfix software). Samples were coated with Pt. Content in TOC was determined by Rock-Eval pyrolysis. The mean geochemical composition of the catchment was estimated from rock and soil compositions by calculating the mean composition (m) of each unit of rocks (UR) and soils (US): mUR1, mean of $n=22$ samples, mUR2 $(n=8)$, mUR3 [ $n=3$, values of Lenselink et al. (1990)], mUS1 $(n=26)$, mUS2 $(n=15)$ and mUS3 $(n=6)$. After that, the mean geochemical compositions of rocks and soils were calculated for the whole catchment, weighting the mean rock and soil unit compositions per their outcropping surfaces (Fig. 3), calculated using ArcGIS (ArcMapArcInfo) software.

\section{Chronology of the lacustrine sediments}

Eighteen ${ }^{14} \mathrm{C}$ dates were obtained from the CDR (Centre de Datation par le Radiocarbone, Lyon 1 University) on seeds, charcoal and bulk sediment organic matter. ${ }^{14} \mathrm{C}$-ages BP were converted into calibrated ${ }^{14} \mathrm{C}$-ages BP in years using the INTCAL 98 calibration curve (Stuiver et al. 1998). Uncertainty was $2 \sigma$ for calibrated dates. The chronological model was 
further completed using pollen, tephrochronology and archeological data (Fourmont et al. 2006; Trément et al. 2007).

\section{Results}

Catchment rock and soil composition

Geochemical compositions of catchment rocks and soils were plotted on a triangular diagram (Fig. 4a). Carbonate-rich marly rocks and soils of $\mathrm{U} 1$ align along a straight line between the $\left[\mathrm{CaO}+\mathrm{MgO}+\mathrm{Na}_{2} \mathrm{O}+\mathrm{K}_{2} \mathrm{O}=\mathrm{CMNK}\right]$ pole and a mix of $\left[\mathrm{Al}_{2} \mathrm{O}_{3}+\mathrm{Fe}_{2} \mathrm{O}_{3}+\mathrm{TiO}_{2}=\mathrm{AFT}\right]$ and $\mathrm{SiO}_{2}$ (1 on Fig. 4a), whereas rocks and soils of units 2 (volcanic materials) and 3 (alluvial materials) are distributed in two distinct areas, respectively, tending to draw nearer the AFT pole (2 Fig. 4a) and $\mathrm{SiO}_{2}$ pole (except two samples) (3 Fig. 4a). The whole catchment composition, calculated from mUR1, mUR2, mUR3, mUS1, mUS2 and mUS3, shows that mUR is moderately enriched in CMNK, especially in $\mathrm{CaO}$, and poorer in $\mathrm{AFT}$ and $\mathrm{SiO}_{2}$ than mUS, but their compositions are quite similar (Fig. 4a). XRD-detected minerals in rocks and soils are calcite $(0-70 \%$ of bulk), dolomite ( $0-35 \%)$, quartz (2-73\%), feldspars $(0-49 \%)$, analcite (0-27\%), augite (0-33\%) and clay minerals (0-60\%) (Fig. 4b). In the clayey fraction, smectite generally dominates $(0-36 \%)$, then illite $(0-34 \%)$ and some kaolinite $(0-5 \%)$. The mineralogical composition varies greatly within each UR or US as shown in Fig. 4b. SEM observations show that calcite presents numerous habits from highly worn clasts to totally pristine crystals of different shapes. However, even though it is abundant, calcite is often indistinguishable at a micron scale, and thus probably constitutes a very fine matrix. Conversely, dolomite is always observed as silt-sized rhombs. Quartz, often abundant, is generally indistinguishable even at a micrometer scale, except in UR3 where it is $\mathrm{mm}$ to $\mathrm{cm}$ : it thus enters into a fine clayey-mixed matrix $(<2 \mu \mathrm{m})$. Feldspars (generally orthoclase, rarely plagioclases) present numerous habits: pristine potassic feldspar crystals of several $\mu \mathrm{m}$ as well as worn clasts. Finally, analcite displays different habits, from big $(>150 \mu \mathrm{m})$, idiomorphic cubic crystals, to small worn clast clusters.

\section{Sarliève lacustrine sediments}

\section{Lithology}

Pit sections and cores revealed four different types of deposits in the sedimentary filling (Fig. 2 and Table 1).

(i) Delta-type sediments (D-type, Fig. 5a). They are 4-5 $\mathrm{m}$ thick and located in the median part of the depression. From base to top, deposits are made up of several units: D1, beige to greenish carbonate-rich clayey-silts (CS) containing encrusted vegetal macrorests; T1, black pyroclastic sands corresponding to unreworked CF1 tephra (Vernet and Raynal 1995;

Fourmont et al. 2006) as shown by heavy minerals and geochemical composition specified in Vernet (2005); D2, alternation of dark tephritic sandy layers reworked from CF1 tephra, with beige carbonate-rich sandy to silty layers; $D 3$, heterometric sandy colluvium topped by a paleosoil; $D 4$, decimeter-thick ochre sandy layer; $D 5$, homogenous greenish calcitic CS, including a 2-cm-thick pale pink tephritic ash layer, T2; T2, called "téphra de Sarliève" (Miallier et al. 2004; Fourmont et al. 2006); D6, charcoal-rich black calcitic CS; D7, greenishgray to brown calcitic CS. Moreover, S177 pit (Fig. 2) showed a 2-m-deep beige to light gray cross-stratified sandy to gravelly D8 unit, cutting up the underlying D6 unit.

(ii) Depocenter basin-type (B-type) sediments. These are the most widespread deposits in the northern and southern parts of the depression (Fig. 2). These deposits, 5-6 m thick, are composed of 6 units, from base to top (Fig. 5a): B1, compact yellowish to greenish CS; B2, light gray-bluish carbonate-rich silty-clays; $B 3$, alternation of centimetrical gray to dark 
brown fairly homogenous CS (HCS) layers with bundles of millimetric carbonate-rich white maculae and laminae (BL), the laminae becoming less frequent and more isolated towards the top in B3; B4, homogenous greenish CS; B5, charcoal-rich black CS; B6; greenish-gray to brown CS.

(iii) Proximal basin deposits. The different successions of facies in the piles present similar features: deposits are 4-4.5 m thick and contain black sandy layers in their lower part (T1b), similar to the T1 tephritic ash layer or the black reworked sands of the D2 unit. Facies forming the upper part of proximal and depocenter basin deposits (B4-B6 units) are similar. (iv) Border and outlet-type deposits. Terrestrial, coarse-grained materials, such as sandy to gravelly colluvium or carbonate-rich mud flow deposits, are found mainly in the lower part.

\section{Chronological model}

The lacustrine sediment chronology was obtained by combining tephra deposit ages, $18{ }^{14} \mathrm{C}$ dates, pollen analysis on SP4 pit and S2 core sediments, and archaeological data. The T1 unit of black pyroclastic sands in D-type deposits corresponds to unreworked "CF1" tephra deposited around $13.7 \pm 0.4 \mathrm{ka}$ cal BP (Vernet and Raynal 1995). T2 tephra, unknown until now, cannot be used for dating (Fourmont et al. 2006). ${ }^{14} \mathrm{C}$ dates range from $11.46 \pm 0.23 \mathrm{ka}$ cal BP to $1.86 \pm 0.14 \mathrm{ka}$ cal BP (Table 2$).{ }^{14} \mathrm{C}$ ages obtained on seeds and charcoal are in stratigraphic order and are consistent with previous chronologies on pollen (de Beaulieu et al. 1988; Guenet and Reille 1988; Argant and Cubizolle 2005; Argant and Prat in Fourmont et al. 2006), whereas bulk sediment dates appear more than 1 ka too old (Fig. 6). Archaeological prospections (Trément et al. 2007) provide evidence that D5 and B4 sediments were deposited up to 300 a BC, and D6 and B5 were deposited after the second century $\mathrm{AD}$, which is in line with $\mathrm{D} 6$ and $\mathrm{B} 5$ charcoal ${ }^{14} \mathrm{C}$ dates (Fig. 6); this implies a hiatus of five centuries in sedimentation. From archaeological remains, Vernet (in Trément et al. 2007) has proposed that D8 was deposited between the fourth and tenth centuries AD. Ages of sediments based on a combination of these data are shown in Fig. 5b.

Sediment facies, stratigraphy and geometry, together with geotechnical tests and ${ }^{14} \mathrm{C}$ dates, allowed N-S and W-E cross-sections to be drawn through the deposits (Fig. 5b). These sections show that a large sandy body in the D unit (delta) zone partly separates the north and south basin bodies composed of B-type units (Fig. 5b N-S section). However, geotechnical tests provide evidence of a corridor made of low-resistance clayey to silty sediments $(<2 \mathrm{Mpa})$, interconnecting the southern and northern basins. In the delta zone, these tests also identified (1) a lower sandy body (set of T1 to D4 units, Fig. 5a), situated between $341 \pm 1 \mathrm{~m}$ and about $343 \mathrm{~m}$ altitude, connected to the western and eastern banks of the paleolake and systematically overlying fine-grained sediments, and (2) an upper sandy body (D8 unit, from $344 \pm 1 \mathrm{~m}$ to $346.5 \pm 0.5 \mathrm{~m}$ ), located only along the eastern bank. The bottom of lacustrine piles lies at an altitude of about $339 \mathrm{~m}$ in the northern basin, 339/340 $\mathrm{m}$ in the delta zone, and about $338 \mathrm{~m}$ in the southern basin (Fig. $\underline{5}$ b, W-E section); thus, the altitude of the northern basin bottom is slightly higher than the southern one. The top of the sediments is at about $344 \mathrm{~m}$, but slightly higher in the delta zone than in the border and outlet zones. Sediments are about $6 \mathrm{~m}$ thick at the maximum. The longitudinal $\mathrm{N}-\mathrm{S}$ section (Fig. 5b) indicates that the outlet zone corresponds to a threshold, marked by a substratum altitude up to about $343 \mathrm{~m}$. Unit similarities appear between basin and delta deposits: there is a clear correlation between the D6 and B5 black charcoal-rich layers over the whole lake area, confirmed by pollen content of sediments (Fourmont et al. 2006). Boundaries between B1 and B2, and B2 and B3 
are at about $339 \mathrm{~m}$ and $339.5 \mathrm{~m}$, respectively, in the southern basin, whereas they are about $0.5 \mathrm{~m}$ higher in the northern basin. There is no clear facies similarity between the D1D4 units or the B1-B3 units. Nevertheless, it is possible to correlate T1 and D2, containing in situ and reworked "CF1" tephra respectively, and B1, containing abundant authigenic zeolites, a by-product of "CF1" tephra alteration (Fourmont et al. 2006).

\section{Composition of lacustrine sediments}

Geochemical and mineralogical analyses were mainly performed on B-type sediments because they are the most abundant in the lacustrine fill (Figs. 2, 5) and are representative of the sedimentation processes. Geochemical composition of sediments sampled in B1-B6 basin units (silty-clayey deposits mainly collected in the S17 core), and D1 (clayey silts), T1 (tephra) and $\mathrm{T} 1 \mathrm{~b}$ deltaic units, were plotted on a CMNK $\left(\mathrm{CaO}+\mathrm{MgO}+\mathrm{Na}_{2} \mathrm{O}+\mathrm{K}_{2} \mathrm{O}\right)-\mathrm{AFT}$ $\left(\mathrm{Al}_{2} \mathrm{O}_{3}+\mathrm{Fe}_{2} \mathrm{O}_{3}+\mathrm{TiO}_{2}\right)-\mathrm{SiO}_{2}$ diagram (Fig. 7a). With the exception of $\mathrm{T} 1$ and $\mathrm{T} 1 \mathrm{~b}$ samples, all values align along a straight line between the $\mathrm{CMNK}$ pole, and a mix of $\mathrm{AFT}-\mathrm{SiO}_{2}$. Plots of mUR and mUS are located on this line (Fig. 7a). With the exception of B1 samples and some B3 samples, lacustrine sediments appear richer in CMNK than the mean geochemical composition of the catchment (mUR and mUS), especially B2 and laminated B3 sediments. However, AFT contents are slightly higher in T1 and T1b samples, which have quite similar geochemical compositions to B1 sediments. B4-B6 sediment chemical compositions are fairly homogenous, while B3 sediment composition varies greatly. Total carbonate contents of bulk sediment vary from 1\% (middle of B1) to 73\% (top of B2) (Fig. 7b). Lacustrine carbonates include calcite, dolomite and aragonite. Calcite (0-47\%) generally dominates the carbonate fraction, except in B2 and the lower third part of B3 units, which are dolomitedominated. Calcite content fluctuates in B1-B3 (about 0-40\%) and varies slightly (about 35$40 \%)$ in B4-B6. Dolomite content (0-68\%) increases steadily from the base to top of B2 where it constitutes up to $68 \%$ of sediments, varies greatly in B3, then stabilizes (about 10 $15 \%$ ) in the top units. Aragonite (maximum 8\%) appears at the B2/B3 transition and in $\mathrm{BL}$ laminae of B3 unit $(<6 \%)$. A close-up of an HCS (homogenous clayey silts)/BL (carbonated bundles and laminae) sequence in B3 unit (Fig. 7b) shows that HCS layers contain less carbonate than BL layers. From HCS to BL we observed the following: the occurrence of white maculae of aragonite, with an increase in total carbonate, particularly dolomite (Ia Fig. $7 b$ ); then the occurrence of thin white laminae with a high dolomite content (Ib); followed by an increase in the proportion of white maculae and also a marked increase in aragonite content (II). In overlying HCS, total carbonate content decreases, aragonite disappears, and dolomite decreases to relatively stable values (about $20 \%$ of carbonates, which is equivalent to $8 \%$ of total sediment). Main carbonate habits observed by means of SEM (Bréhéret et al. 2008) are the following: calcite: (C1) occasional bioclasts (ostracods), (C2) more or less worn crystals and undifferentiated polycrystalline clusters of different sizes, and (C3) nano-micrometric crystals of different habits; Ca-rich dolomite: (Do1) more or less worn and broken silt-sized rhombs, and (Do2) tiny pristine nano- to microspherical crystal clusters; aragonite: (Ar1) rare shell fragments and (Ar2) micrometric pristine crystal bundles of acicular to ellipsoidal shape (rice grains or needles). The $\mathrm{C} 1, \mathrm{C} 2$ and $\mathrm{C} 3$ habits were observed in all calcitic sediments. Do1 is present in all dolomite-containing units, and Do2 in B2 and B3 laminae (Ia and Ib, Fig. 7b). Ar1 was observed in B4-B6 units, Ar2 at B2/B3 transition and in BL of B3. Except in B2 and in lower B3 units, silicates are generally slightly more abundant than carbonates, particularly in the quartz-rich B1 unit (Fig. 7b). Quartz (7$56 \%)$, feldspar (0-32\%) and clay mineral (0-32\%) contents vary greatly in B1, B2 and B3 units, and then become relatively stable in B4-B6. Clay minerals comprise smectite, illite and kaolinite. Smectite dominates in B1, and then decreases from the base to top of B2 where 
illite largely dominates. In HCS of B3, in B4 and in B5, smectite constitutes $2 / 3$ of clay fractions. Kaolinite is always present, but in very low proportions. Zeolites are present in B1 (maximum 22\%), and occur occasionally in B4 and B6 (up to 10\%). As specified in Fourmont et al. (2006), B1 unit contains abundant analcite in the middle part of the depocenter, whereas clinoptilolite occurs around this area. Main habits observed by SEM are the following: quartz: (Q1) silt-sized worn and broken fragments, and (Q2) often indistinguishable even if abundant, probably forming micro and/or nanocrystals mixed with clays; feldspars: (F1) worn and broken as well as pristine plagioclases, and (F2) potassic feldspars; zeolite (only analcite was observed): (Z1) worn and broken silt-sized clasts, (Z2) filling of lens-shaped cavities, and (Z3) pristine silt-sized cubic crystals. Except for the B1 unit, enriched in Q2 quartz, and containing $\mathrm{Z} 2$ and $\mathrm{Z} 3$ zeolite habits, silicate habits are not noticeably distributed in sediments. In $\mathrm{B}$ facies, TOC content varies from 0 to $4.7 \%$ (generally $<3 \%$ ).

\section{Discussion}

\section{Detrital versus biochemical origin of lacustrine sediments}

Mineralogical and geochemical analyses showed that the composition of Sarliève lacustrine sediments is fairly similar to that of the catchment bedrock and soil. Nevertheless, the composition of lacustrine sediments (except B1) tends to be enriched in CMNK $\left(\mathrm{CaO}+\mathrm{MgO}+\mathrm{Na}_{2} \mathrm{O}+\mathrm{K}_{2} \mathrm{O}\right)$ from both mUR and mUS (Fig. 7a). Moreover, because TOC content is always low and because detrital versus biogenic origin of sediment organic matter is difficult to determine with certainty, organic matter was not taken into account in further quantification.

\section{Carbonate origin}

Among carbonates, calcite and dolomite occurred in both lacustrine sediments and catchment rocks and soils, but aragonite only occurred in lacustrine sediments. Dol type (worn or broken rhombs) of dolomite, which presents the same habit as that observed in rocks and soils of the catchment, is clearly detrital. According to Bréhéret et al. (2008), Do2 type of dolomite (pristine crystal clusters) is endogenic; it is related to benthic microbial activities in shallow, brackish to salt-water lakes with strong restriction and water deficit, inducing a high $\mathrm{SO}_{4}{ }^{2-}$ concentration and a high $\mathrm{Mg} / \mathrm{Ca}$ ratio, as observed elsewhere (Vasconcelos et al. 1995; Vasconcelos and McKenzie 1997; Wright 1999; Van Lith et al. 2003). SEM observations show that the B1 unit does not contain dolomite, whereas B2 dolomite is about $100 \%$ endogenic in origin, that B3 HCS (homogenous clayey silts) layers contain only detrital dolomite, whereas interbedded BL (carbonated bundles and laminae) layers mainly consist of endogenic dolomite, and that B4-B6 units contain only detrital dolomite. In the B3 unit, endogenic dolomite constitutes up to $70 \%$ of BL carbonates (Fig. $7 \mathrm{~b}$ ), whereas detrital dolomite constitutes less than $20 \%$ of HCS carbonates. As a result, from proportions of BL and HCS layers in the B3 unit, we calculated that B3 contains on average about $20 \%$ detrital and $80 \%$ endogenic dolomite. For aragonite, the Ar1 facies (shell fragments) is encountered in upper B units, whereas the Ar2 facies (pristine crystals) is encountered in lower B units: B2/B3 transition and in maculae of B3 BL layers. According to Bréhéret et al. (2008), Ar2 is endogenic and bio-induced by unicellular algae or cyanobacteria as shown in other contexts (Müller et al. 1972; Thompson et al. 1997; Douglas and Beveridge 1998; Thompson 2000). This may have occurred during blooms when the water became relatively fresher due to a Carich water supply. Calcite origin is more difficult to determine because it presents various habits and sizes in lacustrine sediments, as in catchment rocks and soils. There can be a considerable amount of detrital calcite in lacustrine sediments derived from carbonate 
catchments (Jones and Bowser 1978). Calcite can also form in situ in a wide variety of lacustrine environments and presents many different habits (Müller et al. 1972; Jones and Bowser 1978; Folk 1999), and it is therefore very difficult to establish relationships between its morphology and origin. The enrichment in CMNK and the relative abundance of calcite in B3-B6 sediments compared to catchment rocks and soils suggests that part of the Sarliève lacustrine sediment calcite results from in situ formation. Because the origin of calcite could not be determined from the mineralogical studies, a method of quantifying the proportion of calcite formed in situ is proposed below.

\section{Silicate origin}

Silicates identified in lacustrine sediments, as in catchment rocks and soils, are: quartz, feldspars, zeolites and clay minerals. Even if zeolites are not the most abundant silicates in lacustrine sediments, their presence may reveal particular conditions of sedimentation. Zeolites were observed in B1, B3 and B4-B6 units. According to Fourmont et al. (2006), particularly abundant zeolites (clinoptilolite or analcite) encountered in the B1 unit have an authigenic origin: Z2 (filling of lens-shaped cavities) and Z3 (pristine cubic crystals) habits would have resulted from in situ crystallization due to reactions between CF1 tephra and brackish to saline and/or alkaline waters, with lowstand water levels, as shown in different endorheic basins (Teruggi 1964; Hay 1966; Sheppard and Gude 1968, 1969, 1973; Surdam and Parker 1972; Surdam and Eugster 1976). This explains why CF1 tephra is generally absent in the B1 unit, while zeolites with Z1 habit (worn and broken clasts) observed in B4B6 units probably result from detritism. Quartz is ubiquitous in lacustrine sediments. Q1 microfacies (large worn and/or broken clasts) probably correspond to detrital inputs from the catchment. The question of quartz origin is raised for the very abundant, tiny, indistinguishable crystals of B1. These features seem to exist in rocks and soils, but taking into account the brackish to saline and/or alkaline waters during B1 deposition, quartz authigenesis is possible, as shown by Surdam and Eugster (1976) in Lake Magadi, where volcanic glass has been modified in alkaline brine. Moreover, authigenic quartz is often described as associated with analcite and potassic feldspars (Sheppard and Gude 1969, 1973). Authigenic potassic feldspars may form in various environmental conditions, lithology and ages (Hay 1966). They have been described in salt-lake sediments, due to contact between salt water and volcanic glass, as the end product of a paragenetic sequence: unweathered glassalkaline zeolite-analcite-potassic feldspars (Sheppard and Gude 1968, 1969, 1973). However, in Sarliève sediments, unlike the quartz enrichment in B1, feldspars (plagioclases and potassic) are distributed throughout the sediments without any particular relation with a sedimentary facies. Clay minerals are similar in Sarliève lacustrine sediments and in catchment rocks and soils: smectite, illite and kaolinite. Except for the B2 unit clay fraction, enriched in illite, clay minerals forming lacustrine sediment are dominated by smectite, in similar proportions to that of carbonate-rich marly rocks and soils, and we therefore assume that they are mainly inherited as defined by Millot (1964). Nevertheless, smectite authigenesis is possible in a lacustrine environment, especially if volcanic glass is in contact with salty alkaline waters (Lemoalle and Dupont 1973; Müller and Förstner 1973; Jones and Bowser 1978; Tettenhorst and Moore 1978; Chamley 1989), as occurred during B1 unit deposition. Moreover, illite enrichment in the B2 unit could be due to smectite transformation, as observed in sediments deposited in brine in contact with volcanic glass (Singer and Stoffers 1980). Even if smectite and illite authigenesis conditions occurred temporarily (during B1 and B2 unit deposition), the proportion of authigenic clays is probably low: clay mineral content generally represents less than $12 \%$ of $\mathrm{B} 1$ and $\mathrm{B} 2$ sediments. 


\section{Quantification of detrital versus biochemical phases in sediments}

Previous mineral study suggests that, except in B1, silicates are mainly detrital, and in situ precipitated minerals are generally carbonates. Consequently, a method was developed to quantify the detrital versus in situ (biochemical) carbonate phases in the B2-B6 units. Because $\mathrm{Mg}$ and Ca contents in Sarliève sediment silicates are very low, they can be neglected and it is assumed that $\mathrm{Mg}$ and $\mathrm{Ca}$ contents in bulk are mainly due to carbonates. Proportions of $\mathrm{MgO}$ and $\mathrm{CaO}$ in carbonates due to precipitation from dissolved matter (called $\mathrm{MgOprec}$ and $\mathrm{CaOprec}$ ) were estimated. It is assumed that respective contents of $\mathrm{MgOprec}$ and $\mathrm{CaO}$ prec versus detrital $\mathrm{MgO}$ and $\mathrm{CaO}$ (MgOdet and CaOdet) are representative of biochemical versus detrital carbonate proportions in sediments, $\mathrm{MgO}$ content reflecting the dolomite content. In the $\mathrm{B} 2$ unit, about $100 \% \mathrm{MgO}$ of sediments enter authigenic dolomite; in the same way about $80 \% \mathrm{MgO}$ of $\mathrm{B} 3$ belongs to authigenic dolomite, versus $20 \% \mathrm{MgO}$ to detrital dolomite; in $\mathrm{B} 4-\mathrm{B} 6$ units, $100 \% \mathrm{MgO}$ belongs to detrital dolomite. By weighting \% $\mathrm{MgOprec}$ versus \% MgOdet by mean \% MgO of lacustrine sediment bulk in each unit, it was possible to estimate the whole $\mathrm{MgO}$ proportion due to precipitation in sediments $(\% \mathrm{MgOprec}$, Fig. 8a). Estimating precipitated $\mathrm{CaO}$ in calcium carbonates of lacustrine sediments is more difficult because analysis did not provide precise conclusions about the origins of these minerals: calcium carbonate contents correspond both to inherited (calcite and dolomite) and precipitated (calcite, dolomite and traces of aragonite) minerals. Thus, comparison of mean $\mathrm{CaO} \%$ of catchment, on the one hand, and lacustrine sediments on the other, reveals possible in situ precipitation of calcium carbonates, if we consider that non-carbonate minerals (mainly silicates) did not change during the transfer from the sediment source (catchment rocks and soils) to the lake; similar $\mathrm{CaO} \%$ would show that lacustrine carbonates are only detrital in origin, whereas $\mathrm{CaO}$ enrichment in lacustrine sediments could indicate carbonate precipitation. As sediments in B2-B6 units were deposited from the beginning of the Holocene until recent times, one must consider that the composition of erodible material in the catchment evolved during that time: (1) at the end of the glacial period, during the Late Glacial and the beginning of the Holocene, soils were still weakly developed as a result of surface periglacial processes (solifluction, mud flow) (Jeambrun et al. 1973); (2) during the early and middle Holocene, as a result of climate improvement, vegetation development and higher slope stability, soils developed and were thicker, as often observed elsewhere in France (Revel and Rouaud 1985; Bertran 2004); (3) present soils are the result of modern alteration of flux and inputs of matter on their surface, due to human activities (Revel and Rouaud 1985; Lang and Hönscheidt 1999; Zolitschka et al. 2003). Thus, mean $\mathrm{CaO} \%$ of eroded solid materials was (1) close to the mean $\mathrm{CaO} \%$ of catchment rocks during the Late Glacial and the lower Holocene (mUR, Fig. 4a), and (3) close to the mean $\mathrm{CaO} \%$ of present soils during the upper Holocene (mUS, Fig. 4a). Due to rock weathering since the Last Glacial Maximum, there was a decrease in the $\mathrm{CaO}$ and $\mathrm{MgO}$ contents, which may have partly supplied lacustrine authigenic carbonates. On the other hand, we can assume that $\mathrm{CaO}$ content in deep soils of the Atlantic period (2) could not be higher than $\mathrm{CaO}$ content in the HCS facies of the $\mathrm{B} 3$ unit, which is mainly detrital in origin. As a major part of lacustrine $\mathrm{SiO}_{2}, \mathrm{Al}_{2} \mathrm{O}_{3}$ and $\mathrm{Fe}_{2} \mathrm{O}_{3}$ results from detritism, whereas $\mathrm{CaO}$ belongs to both detrital (\%CaOdet) and precipitated (\%CaOprec) sedimentation, $\mathrm{CaO}$ enrichment in lacustrine sediments due to precipitation was calculated by comparing $\mathrm{rL}$ and $\mathrm{rC}$ ratios in lacustrine sediments (L) and in the catchment $(\mathrm{C})$ respectively:

\section{$\mathrm{IL}=(\% \mathrm{CaO}$ det $+\% \mathrm{CaO}$ pree $) /\left(\mathrm{SHO}_{2}+\% \mathrm{Hl}_{2} \mathrm{O}_{3}+\% \mathrm{FeO}_{3}\right)$}

with $(\% \mathrm{CaOdet}+\% \mathrm{CaOprec})$ equal to total lacustrine sediment $\mathrm{CaO}$. 


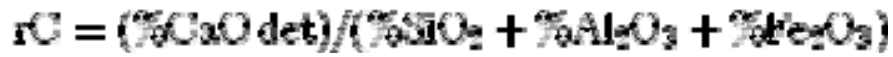

with \%CaOdet equal to catchment mean $\mathrm{CaO}$ content.

The value of $\mathrm{rC}$ during the Late Glacial and the early Holocene was close to the mean bedrock value of $\% \mathrm{CaO} /\left(\% \mathrm{SiO}_{2}+\% \mathrm{Al}_{2} \mathrm{O}_{3}+\% \mathrm{Fe}_{2} \mathrm{O}_{3}\right)($ or $\mathrm{CaO} / \mathrm{SAF})=\operatorname{rmUR}(1$ in Fig. $8 \mathrm{~b})$ because soils were very thin and erosion mainly affected bedrock. During the middle Holocene, when soils were the thickest and the poorest in carbonates, $\mathrm{rC}$ value could not be higher than the $\mathrm{CaO} / \mathrm{SAF}$ value observed in the less carbonate-rich facies of the B3 unit (rmHCS: 2 in Fig. 8b). During the Late Holocene, $\mathrm{rC}$ came closer to the $\mathrm{CaO} / \mathrm{SAF}$ mean value of present soils (rmUS: 3 in Fig. 8b). Assuming that lacustrine silicates are mainly detrital in origin, we considered that SAF in $\mathrm{rL}$ is equal to $\mathrm{SAF}$ in $\mathrm{rC}$. Thus, the difference between $\mathrm{rL}$ and $\mathrm{rC}$ for each sample corresponds to \%CaOprec in sediments from B2 to B6 (Fig. 8b). Figure 8c presents $\% \mathrm{MgOprec}$ and $\% \mathrm{CaOprec}$ versus \% oxides in detrital minerals calculated from S17 core lacustrine sediments. In the lower part of the dolomitic B2 unit, about $30 \%$ of all sediments were precipitated; the precipitated phase increased up to $60 \%$ in the upper part of B2 at ca. $8 \mathrm{ka}$ cal BP. Values decreased in B3 where they varied greatly (close to $0 \%$ at about $6.5 \mathrm{ka}$ cal BP up to more than $60 \%$, with highest values in BL facies). From B4 to B6 units, the precipitated phase varied between 10 and $20 \%$. The unusual B1 unit was deposited while the normally carbonate-dominated rocks and soils of the catchment temporarily changed into silicate-dominated terrain as a result of CF1 tephra fallout. By comparing $\mathrm{SiO}_{2}$ and $\mathrm{Al}_{2} \mathrm{O}_{3}$ contents in sediments on the one hand, and in catchment rocks on the other, and considering $\mathrm{TiO}_{2}$ to be constant, it was estimated that $35-40 \%$ of silicates were formed in situ from tephra dissolution (Fourmont 2005) (Fig. 8c). In D-type sediments, the same calculation shows that the D1 unit contains ca $28 \%$ CaOprec. The T1 unit corresponds to allochthonous unweathered tephra, and D2-D4 units clearly consist of only coarse detrital sediments. Origins of carbonates are similar in overlying D5-D7 deltaic units and B4-B6 basin units.

\section{Paleohydrology evolution in the lake}

\section{Dry Late Glacial and early Holocene periods}

During the Late Glacial, up to ca. 13.7 ka cal BP (mainly Bölling), D1 unit sediments, containing about $30 \%$ travertine-like precipitated material, were deposited in the delta area (Fig. 9a). No evidence of coeval sediments was found in basins; either they were dry, and/or input of matter to the depression was low and stored only in the delta area. Maximum water depth could have been about $5 \mathrm{~m}$ (difference between present altitudes of paleolake bottom and outlet level) (Fig. 9a), but it was probably much lower when formation of the lacustrine depression began. During the Bölling, vegetation composed of open Betula and Juniperus forest (de Beaulieu et al. 1988) was not sufficiently developed to support significant evapotranspiration in the basin, so the lowstand in lacustrine water level may indicate a relative dryness during a cool climate period. At ca. $13.7 \mathrm{ka}$ cal BP (ca. beginning of Alleröd), direct CF1 tephra was deposited (T1 unit, Fig. 9b). Although it probably covered the whole catchment area, it was only observed in delta sediments (Fig. 5), in traces (CF1-like materials) in proximal basins, but never in distal basin sediments. In the delta area, CF1 tephra was buried under the D2 unit, and deposited in a fan-type delta, according to the definition of Nemec and Stell (1988), during the 13.7-11.5 ka cal BP period (Alleröd and Younger Dryas) (Figs. 5 and 9c). The D2 unit, exclusively detrital in origin, includes layers of tephra reworked from catchment slopes. This sedimentary phase suggests increase in water level during flood 
event(s), rising above the topset, i.e. higher than about $342 \mathrm{~m}$ (Figs. 5b, 9c), which probably led to a short-lived opening of the lacustrine depression. However, during the same period, from $13.7 \mathrm{ka}$ cal BP up to ca. $9.8 \mathrm{ka}$ cal BP (Fig. 9c, d), authigenic zeolites and quartz formed in distal basin B1 unit, from CF1 glass dissolution in salty and alkaline water (Fourmont et al. 2006), showing endorheic conditions with generally low water levels and reduced detrital input (about $60 \%$ of B1 sediments); authigenic zeolites and quartz were formed by geochemical processes, as long as tephra material was available in the catchment, apparently up to ca. $9.8 \mathrm{ka}$ cal BP. Salt concentration in basin waters was due mainly to dissolution of salts (principally gypsum) contained in Oligocene bedrock (Jeambrun et al. 1973). Thus, during the Alleröd and the Younger Dryas periods, the lake was generally closed and the water level low: the cool (Alleröd) and cold (Younger Dryas) climates (Johnsen et al. 1992; Peteet 1995; Anderson 1997) were probably relatively dry with some strong rain and runningwater events. It is possible that tephra fallout altered vegetational cover, mainly composed of Betula and Pinus forest during the Alleröd (de Beaulieu et al. 1988), and encouraged run-off for several years or decades. The fan delta was probably deposited over a relatively long time, especially in the "tundra" context during the Younger Dryas, up to complete erosion of tephra cover in the catchment; detrital material was not transported to basins because of high energy dissipation in the unconstrained fan delta (Rachocki 1981). After ca. 11.5 ka cal BP (early Holocene), colluvium (D3 unit) was deposited in the emerged delta area (Fig. 9d); siltage was probably time-limited as shown by marked soil development at the top of D3. Topsoil probably formed during the early and the middle Holocene up to the end of the Atlantic period (Fig. 9d-f). At the same time, authigenic dolomite-rich sediments (B2 unit) were deposited until ca. $7.5 \mathrm{ka}$ cal BP from carbonates dissolved in catchment soils, because of perennial endorheic conditions with salty and alkaline water in basins (Fig. 9e). Biochemical dolomite content increased in sediments, from 30\% (B2 bottom) to 60\% (B2 top), the highest value being around $8 \mathrm{ka}$ cal BP, indicating increased shrinkage of the water body. The water level did not reach the top of D3, and the water was probably shallow ( $<1-2 \mathrm{~m}$ deep) (Fig. 9d, e). Thus, perennial endorheic conditions in the Sarliève catchment developed during the Late Glacial and the Lower Holocene periods, and may have been climate-driven. Observed dryness agrees with data obtained in Western Europe: Andrews (2006) showed increasing dryness in Southern England from the Bölling/Alleröd period (12.2 ka cal BP) to Preboreal/Boreal transition. We also observed a peak of dry conditions (dolomite abundance in upper part of B2) at about $8 \mathrm{ka}$ cal BP that could have coincided with the cold and dry event at $8.2 \mathrm{ka}$, broadly recognized in the northern hemisphere at the end of the Boreal period (Carrion 2002; Alley and Agustsdottir 2005; Macklin et al. 2006). Moreover, in the Sarliève catchment, dry Alleröd and Younger Dryas periods were characterized by some strong flood events, with input of sandy materials mainly deposited in the delta area and possibly due to gully erosion of alluvial terraces favoured by scarce vegetation. We did not observe the highstand water level reported by Harrison et al. (1993) at 9 ka cal BP in Southern France, or the alternation of wet and dry periods identified in the Jura by Magny and Ruffaldi (1995) from lake-level variations and glacier retreats during the Late Glacial and Lower Holocene. In the Sarliève catchment, local climatic conditions were characterized by increased drought, leading to playa conditions. Moreover, the catchment/lake surface ratio, which is very low here $(\sim 6)$, probably reduced the hydrological response of the lake level to slight climatic variations. After ca. $11.5 \mathrm{ka}$ cal BP, the absence of evidence of floods and the homogenous distribution of detrital matter (70-40\% of sediment bulk) in basins, indicating limited runoff, may be due to the development of forest cover at that time (de Beaulieu et al. 1988). 


\section{Alternately dry and wet middle Holocene}

From ca. $7.5 \mathrm{ka}$ cal BP until ca. $5.3 \mathrm{ka}$ cal BP, during the Atlantic period, while the delta area was still never flooded (Fig. 9f), the B3 unit was deposited in basins. Interbedding of laminated biochemical sediments (BL facies) with detrital sediments (HCS facies) shows recurrent modifications in paleohydrology and related deposition conditions. According to Bréhéret et al. (2008), (1) dolomite authigenesis in BL (Ia + Ib, Fig. 7b) corresponds to the mineralization of microbial mats developed under restricted conditions similar to B2 sedimentation conditions; (2) aragonite genesis in BL (II, Fig. 7b) provides evidence of inputs of $\mathrm{Ca}^{2+}$-rich freshwater. Thus, BL facies composed of $20-60 \%$ biochemical phases (Fig. $8 \mathrm{c}$ ) were deposited while the lake waters were salty, until they became fresher; (3) HCS deposition is marked by the increase of a detrital phase in sediments, while biochemical phases constituted less than $10 \%$ of sediment bulk (Fig. 8c). This trend could be related to repeated time-limited fluctuations of the water level which was generally below the top of D3 paleosoil (Fig. 9f), i.e. about 342/343 m. The duration of one BL + HCS sequence of deposition has been evaluated at $0.15-0.46 \mathrm{ka}$ in $\mathrm{S} 17$ core (between $7.1 \pm 0.15 \mathrm{ka}$ cal BP and $7.26 \pm 0.16 \mathrm{ka}$ cal BP). However, the gradual increase of detrital HCS facies towards the top of B3 indicates increasingly frequent fresh water in basins and the possible temporary opening of the system. This repetition of closed and open conditions could be related to climate change. Centennial-scale climate variations during the Holocene have been documented, especially for the time before $4 \mathrm{ka}$ cal BP, in the northern hemisphere (Aaby 1976; Bond et al. 2001; Douglas et al. 2007). Thus it is possible that local hydro-climatic characteristics of the Sarliève catchment accentuated the effect of global climatic changes during the Atlantic. However, Sarliève paleolake hydrology could well have been influenced by changes in the catchment surface area: Neolithic settlements developed during the Atlantic period (Trément et al. 2007). Vegetation was characterized by a thermophilous forest (mixed oak grove) marked by the appearance of cereals, as reported by Gachon (1963) and confirmed by Trément et al. (2007). It is also possible that detrital sediment and freshwater inputs could have been induced by repeated human settlements and deforestation for arable farming and subsequent changes in earth-surface hydrology.

\section{Wet Late Holocene}

Sediment geometry shows that the water level was high from 5.3 ka cal BP during the Subboreal and the Subatlantic: B4-B6 units accumulated while the lake expanded, covering the delta area and border deposits (Fig 9g), as demonstrated by core drillings and geophysical data (Hinschberger et al. 2006). Water-level altitude must have been at least about $343 \mathrm{~m}$ (top of B4/D5, Fig. 9g) at the beginning of the Subboreal, and 344/345 m (top of B6, Fig. 9h) in the 17th century AD. This water level may have been constrained by the deposition of a debris flow on the outlet area, composed of Oligocene marl. Except for the D4 sandy transgressive facies, deposited on a delta paleosoil at the Atlantic-Subboreal transition (Prat in Trément et al. 2007), and local D8 sandy-gravelly deltaic facies, the upper sediments of the whole delta (D5-D7 units) and basin (B4-B6 units) have a homogenous composition. They contain more than $80 \%$ detrital materials, and biochemical calcite is always $<20 \%$. There is no evidence of salt water in Late Holocene sediment composition, and therefore the waters were probably continuously fresh. This implies a perennial water body in the basin, total opening of the depression (Fig. 9h) and continuous water supply from the catchment. Nevertheless, some notable events occurred. Archaeological data show that the lake dried up between the 3rd century BC and 2nd century AD due to human activities, Gallo-Roman settlements with a cemetery and drainage network having been found in the paleolake basins 
(Trément et al. 2007). "Catastrophic" flood(s) occurred between the 4th and 10th centuries $\mathrm{AD}$, causing sandy-gravelly fan-delta deposition (D8 unit), and causing the water level to rise above $346 / 347 \mathrm{~m}$. Finally, the lake was drained during the 17 th century (Fournier 1996), and since then the water has run in artificial channels. The end of restriction in the depression, associated with perennial high water level from ca. $5.3 \mathrm{ka}$ cal BP, could be linked to climate change with increased humidity since the beginning of the Subboreal, as noted in other European areas (Barber et al. 1994; Bertran et al. 1998; Macklin 1999; Hughes et al. 2000; Magny et al. 2006). While Harrison et al. (1993) reported that in Sourthern France lake water levels were lowest at $4 \mathrm{ka}$ and have since risen, Magny (2004) has reported 8 highstand lake water levels since $5.5 \mathrm{ka}$ cal BP in mid-Europe. Nevertheless, hydrology was considerably modified during the Late Holocene due to human activities, settlements developing continuously in the catchment, with a marked peak of activity in the Iron Age and the GalloRoman period (Trément et al. 2007). Deforestation for agriculture inducing decreased evapotranspiration, and increased runoff throughout the catchment, probably reinforced the effect of a more humid climate on wetlands at that time, as found in Britain by Macklin (1999); at Sarliève, abundant fine detrital material, equally distributed in Late Holocene basin sediments, seems to have been yielded by the whole catchment surface. The relative lowstand water level reported by Magny (2004) between 2.35 and $1.8 \mathrm{ka}$ cal BP for lakes in midEurope may have encouraged drainage network development in Iron Age and Gallo-Roman settlements in the Sarliève area. Drastic deforestation can also explain periods of very strong runoff and fan-delta dynamics during the first part of the Middle Ages. This type of hydrodynamics, never previously developed during the Holocene, had only appeared during the Late Glacial period (Alleröd and Younger Dryas), and seems to have been induced by poor vegetational cover.

\section{Conclusions}

The geometry and composition of Sarliève paleolake sediments, together with a model of quantification of detrital versus biochemical components allowed three main hydrological phases to be identified. The first phase, developed during the Late Glacial and early Holocene (13.7-7.5 ka cal BP), was characterized by a dry, either cold or cool climate, with "a dryness peak" at about $8 \mathrm{ka}$ cal BP, leading to a lowstand in water level, endorheism and authigenesis of fairly unusual minerals in temperate areas, such as zeolites and dolomite. Main detrital events (fan-delta) appeared during periods of low vegetation development, temporarily encouraging runoff, especially during the Alleröd and Younger Dryas. The second phase, developed during the middle Holocene (7.5-5.3 ka cal BP), was characterized by multidecadal to centennial alternation of endorheic conditions marked by biochemical authigenesis of minerals, and input of fresh water and detrital material. These hydrologic alternations may be linked to centennial global climatic variations with a general trend to a more humid climate, but they could also have been influenced by the effect of repeated deforestation on the hydrological budget in the catchment due to Neolithic human settlement. The third hydrological phase, developed during the Late Holocene (since $5.3 \mathrm{ka} \mathrm{cal} \mathrm{BP}$ ), is characterized by a high water level and mainly detrital sediment inputs. This change in hydrological conditions and sediment composition may be the result of climate evolution since the beginning of the Subboreal. However, drastic changes in lake hydrology (phases of fan-delta deposition or lake drying) during the last two millennia have been primarily humandriven. The local dry climate of the Sarliève catchment, unusual in Western Europe and accentuating the prevailing hydrological conditions, made it possible to identify the main climate changes since the Late Glacial and the high human impact on lake-water level since the Late Holocene. 
Acknowledgments This work was supported by the French CNRS-INSU ECLIPSE programs "Interactions activités humaines - production et stockage de sédiments à l'Holocène en plaine et en moyenne montagne » and Zone Atelier Loire. We thank J.P. Bakyono, I. Pène and many other collaborators for their help in acquiring field data and sediment analysis, and the Institut National de Recherche d'Archéologie Préventive (INRAP) and the Society Fondasol Auvergne for their collaboration. We thank Miss Yates and A. Latapie for their assistance in translation of this text and two anonymous reviewers for their constructive comments. 


\section{References}

Aaby B (1976) Cyclic climatic variations in climate over the past 5,500 yr reflected in raised bogs. Nature 263:281-284. doi:10.1038/263281a0

Alley RB, Agustsdottir AM (2005) The 8 k event: cause and consequences of a major Holocene abrupt climate change. Quat Sci Rev 24:1123-1149.

doi:10.1016/j.quascirev.2004.12.004

Anadon P, Cabrera L, Kelts K (1991) Lacustrine facies analysis. International Association of Sedimentologists (I.A.S.) Special Publication No. 13. Blackwell Scientific Publications, Oxford

Anderson DE (1997) Younger Dryas research and its implications for understanding abrupt climatic change. Prog Phys Geogr 21:230-249. doi:10.1177/030913339702100203

Andrews JE (2006) Palaeoclimatic records from stable isotopes in riverine tufas: synthesis and review. Earth Sci Rev 75:85-104. doi:10.1016/j.earscirev.2005.08.002

Argant J, Cubizolle H (2005) L'évolution holocène de la végétation des monts de la Madelaine, du Forez, du Livradois et du Pilat (Massif central oriental, France): l'apport d'une nouvelle série d'analyses palynologiques. Quaternaire 16:119-142

Ballut C (2000) Evolution environnementale de la Limagne de Clermont-Ferrand au cours de la seconde moitié de l'Holocène (Massif central français). PhD thesis, University of Clermont-Ferrand

Barber KE, Chambers FM, Maddy D, Stoneman R, Brew JS (1994) A sensitive highresolution record of Late Holocene climatic change from a raised bog in northern England. Holocene 4:198-205. doi:10.1177/095968369400400209

Bertran P (2004) Soil erosion in small catchments of the Quercy region (southwestern France) during the Holocene. Holocene 14:597-606. doi:10.1191/0959683604h1737rp

Bertran P, Fabre L, Franc O, Limondin-Lozouet N, Thièbaut S (1998) Évolution d'un versant au cours de l'Holocène à Vaise (France). Géographie physique et Quaternaire 52, on line: http://www.erudit.org/revue/gpq/1998/v52/n1/index.html

Bond G, Kromer B, Muscheler R, Evans MN, Showers W, Hoffmann S et al (2001) Persistent solar influence on North Atlantic climate during the Holocene. Science 294:2130-2136. doi:10.1126/science. 1065680

Bornand M, Callot G, Favrot JC, Servat E (1968) Les sols du Val d'Allier. INRA Service d'Etude des sols, Montpellier

Bréhéret JG, Fourmont A, Macaire JJ, Négrel P (2008) Microbially mediated carbonates in the Holocene deposits from Sarliève, a small ancient lake of the French Massif Central, testify to the evolution of a restricted environment. Sedimentology 55:557-578. doi:10.1111/j.1365- 
Carrion JS (2002) Patterns and processes of Late Quaternary environmental change in a montane region of southwestern Europe. Quat Sci Rev 2:2047-2066. doi:10.1016/S02773791(02)00010-0

Chamley H (1989) Clay sedimentology. Springer-Verlag, Heidelberg

Dearing JA, Foster IDL (1986) Lake sediments and palaeohydrological studies. In: Berglund B (ed) Handbook of Holocene Palaeoecology and Palaeohydrology. Wiley, Chichester, pp $67-90$

De Beaulieu JL, Pons A, Reille M (1988) Histoire de la flore et de la végétation du Massif Central (France) depuis la fin de la dernière glaciation. Cahier Micropaleontologie 3:5-36

De Göer de Herve A, Boivin P, Camus G, Gourgand A, Kieffer G, Mergoil J, Vincent PM (1991) Volcanologie de la Chaîne des Puys - Livret de la carte géologique

Derruau M (1949) La grande Limagne auvergnate et bourbonnaise, Etude géographique. Thesis, University of Grenoble

Détriché S, Bréhéret JG, Zarki H, Karrat L, Macaire JJ, Fontugne M (2008) Late Holocene palaeohydrology of lake Afourgagh (Middle-Atlas, Morocco) from deposit geometry and facies. Bull Soc Geol Fr 179:41-50. doi:10.2113/gssgfbull.179.1.41

Digerfeldt G (1986) Studies on past lake-level fluctuations. In: Berglund B (ed) Handbook of Holocene Palaeoecology and Palaeohydrology. Wiley, Chichester, pp 127-143

Douglas S, Beveridge TJ (1998) Mineral formation by bacteria in natural microbial communities. FEMS Microbiol Ecol 26:79-88. doi:10.1111/j.1574-6941.1998.tb00494.x

Douglas R, Gonzalez-Yajimovich O, Ledesma-Vazquez J, Staines-Urias F (2007) Climate forcing, primary production and the distribution of Holocene biogenic sediments in the Gulf of California. Quat Sci Rev 26:115-129. doi:10.1016/j.quascirev.2006.05.003

Folk RL (1999) Nannobacteria and the precipitation of carbonate in unusual environments. Sediment Geol 126:47-55. doi:10.1016/S0037-0738(99)00031-7

Fourmont A (2005) Quantification de l'érosion et de la sédimentation dans le bassin de Sarliève (Massif central, France) au Tardiglaciaire et à l'Holocène. Impact des facteurs naturels et anthropiques. PhD thesis, University of Tours

Fourmont A, Macaire JJ, Bréhéret JG, Argant J, Prat B, Vernet G (2006) Tephras in lacustrine sediments of the Sarliève marsh (French Massif Central): age and preservation. C R Geosci 338:1141-1149. doi:10.1016/j.crte.2006.09.013

Fournier G (1996) Sarliève: un lac au moyen âge. Assoc Site Gergovie 11:2-34

Gachon L (1963) Contribution à l'étude du quaternaire récent de la Grande Limagne marnocalcaire: morphogenèse et pédogenèse. Thesis, University of Clermont-Ferrand 
Gasse F, Fontes JC, Plaziat JC, Carbonel P, Kaszmarska I, De Deckker P et al (1987) Biological remains, geochemistry and stable isotopes for the reconstruction of environmental and hydrological changes in the Holocene lakes from North Sahara. Palaeogeogr Palaeocl 60:1-46. doi:10.1016/0031-0182(87)90022-8

Gregory KJ, Maizels JK (1991) Morphology and sediments: typological characteristics of fluvial forms and deposits. In: Starkel L, Gregory KJ, Thornes JB (eds) Temperate Palaeohydrology. Wiley, Chichester, pp 30-59

Guenet P, Reille M (1988) Analyse pollinique du lac-tourbière de Chambedaze (Massif Central, France) et datation de l'explosion des plus jeunes volcans d'Auvergne. B Assoc Fr Etud Quatern 4:175-194

Håkanson L, Jansson M (1983) Principles of lake sedimentology. Springer Verlag, Heidelberg

Harrison S, Digerfeldt G (1993) European lakes as palaeohydrological and palaeoclimatic indicators. Quat Sci Rev 12:233-248. doi:10.1016/0277-3791(93)90079-2

Harrison SP, Metcalfe SE (1985) Variations in lake levels during the Holocene in North America: an indicator of changes in atmospheric circulation pattern. Geogr Phys Quatern 39:141-150

Harrison SP, Prentice IC, Guiot J (1993) Climatic controls on Holocene lake-level changes in Europe. Clim Dyn 8:189-200. doi:10.1007/BF00207965

Hay RL (1966) Zeolite and zeolitic reactions in sedimentary rocks. Geol Soc Am Bull 85:130

Hinschberger F, Fourmont A, Macaire JJ, Bréhéret JG, Guérin R (2006) Contribution of geophysical surveys to the study of fine grained lacustrine sediments. Application to the Sarliève marsh (Massif Central, France). Bull Soc Geol Fr 177:311-322.

doi:10.2113/gssgfbull.177.6.311

Hughes PD, Mauquoy D, Barber KE, Langdon PG (2000) Mire development pathways and paleoclimatic records from a full Holocene peat archive at Walton Moss, Sumbria, England. Holocene 10:465-479. doi:10.1191/095968300675142023

Jeambrun M, Aubert M, Bouiller R, Camus G, Cochet A, d'Arcy D, Giot D, Baudry D, Roche A, Bonhommet N (1973) Carte géologique à 1/50000 de Clermont-Ferrand XXV-31

Johnsen SJ, Clausen HB, Dansgaard W, Fuhrer K, Gundestrup NS, Hammer CU et al (1992) Irregular glacial interstadials recorded in a new Greenland ice core. Nature 359:311-313. doi:10.1038/359311a0

Jones BF, Bowser HP (1978) The mineralogy and related chemistry of lake sediments. In: Lerman A (ed) Lakes: chemistry, geology,physics. Springer Verlag, New York, pp 179-235

Kessler J, Chambraud A (1986) La météo de la France. Tous les climats localité par localité. Lattès JC 
Lamb HF, Eicher U, Switsur VR (1989) An 18000-year record of vegetation, lake-level and climatic change from Tigalmamine, Middle-Atlas, Morocco. J Biogeogr 16:65-74.

doi:10.2307/2845311

Lang A, Hönscheidt S (1999) Age and source of colluvial sediments at Vaihingen-Enz, Germany. Catena 38:89-107. doi:10.1016/S0341-8162(99)00068-5

Lemoalle J, Dupont B (1973) Iron bearing oolites and the present conditions and the present conditions of iron sedimentation in lake Chad (Africa). In: Amstutz G, Bernard AJ (eds) Ores in sediments. Springer, Berlin, pp 167-178

Lenselink G, Kroonenberg SB, Loison G (1990) Pleniglacial to Holocene paleo-environments in the Artière basin in the western Limagne rift valley, Massif Central, France. Quaternaire 2:139-156

Lezine AM, Casanova J (1991) Correlated oceanic and continental records demonstrate past climate and hydrology of North Africa (0-140 ka). Geology 19:307-310. doi :10.1130/00917613(1991)019<0307:COACRD $>2.3 . \mathrm{CO} ; 2$

Macaire JJ, Bernard J, Di-Giovanni C, Hinschberger F, Limondin-Lozouet N, Visset L (2006) Quantification and regulation of organic and mineral sedimentation in a Late Holocene floodplain as a result of climatic and human impacts (the Taligny marsh, Parisian Basin, France). Holocene 16:647-660. doi:10.1191/0959683606h1961rp

Macklin MG (1999) Holocene river environments in prehistoric Britain: human interaction and impact. Quatern Proc 7:521-530. doi :10.1002/(SICI)1099-1417(199910)14:6<521::AIDJQS487>3.0.CO;2-G

Macklin MG, Benito G, Gregory KJ, Johnstone E, Lewin J, Michczynska DJ et al (2006) Past hydrological events reflected in the Holocene fluvial record of Europe. Catena 66:145-154. doi:10.1016/j.catena.2005.07.015

Magny M (1992) Holocene lake level fluctuations in Jura and the northern subalpine ranges, France: regional pattern and climatic implications. Boreas 21:319-334

Magny M (1993) Holocene fluctuations of lake-level in the French Jura and Subalpine ranges, and their implications for past general circulation pattern. Holocene 3:319-334. doi:10.1177/095968369300300402

Magny M (1998) Reconstruction of Holocene lake-level changes in the Jura (France): methods and results. In: Harrison SP, Frenzel B, Huckried U, Weiss M (eds) Palaeohydrology as reflected in lake-level changes as climatic evidences for Holocene times.

Paläoklimaforschung, Stutgart, pp 67-85

Magny M (2001) Palaeohydrological changes as reflected by lake-level fluctuations in the Swiss Plateau, the Jura Mountains and the northern French Pre-Alps during the last GlacialHolocene transition: a regional synthesis. Global Planet Change 30:58-101. doi:10.1016/S0921-8181(01)00080-7 
Magny M (2004) Holocene climate variability as reflected by mid-European lake-level fluctuations and its probable impact on prehistoric human settlements. Quaternary Int 113:6579. doi:10.1016/S1040-6182(03)00080-6

Magny M, Ruffaldi P (1995) Younger Dryas and early Holocene lake-level fluctuations in the Jura mountains, France. Boreas 24:155-172

Magny M, Leuzinger U, Bortenschlager S, Haas JN (2006) Tripartite climate reversal in central Europe 5600-5300 years ago at Arbon-Bleiche, Switzerland. Quat Res 65:3-19. doi:10.1016/j.yqres.2005.06.009

Miallier D, Sanzelle S, Pilleyre T, Vernet G, Brugière S, Danhara T (2004) Nouvelles données sur le téphra de Sarliève et le téphra CF7, marqueurs chronostratigraphiques de Grande Limagne (Massif Central, France). C R Geosci 336:1-8.

doi:10.1016/j.crte.2003.10.017

Michel R (1948) Etude géologique du plateau de Gergovie. Mémoire des Sociétés d'histoire naturelle d'Auvergne 4:1-68

Millot G (1964) Géologie des argiles. Masson, Paris

Morange A, Heritier F, Villemin J (1971) Contribution de l'exploration pétrolière à la connaissance structurale et sédimentaire de la Limagne, dans le Massif Central. In Plein Air (ed) Symposium Jung J, Clermont Ferrand

Müller G, Förstner U (1973) Recent iron ore formation in lake Malawi Africa. Mineral deposits 8:278-290

Müller G, Irion G, Förstner U (1972) Formation and diagenesis of inorganic $\mathrm{Ca}-\mathrm{Mg}$ carbonates in the lacustrine environment. Naturwissenschaften 59:158-164.

doi:10.1007/BF00637354

Nemec W, Stell RJ (1988) What is a fan delta and how do we recognize it? In: Nemec W, Steel RJ (eds) Fan delta: sedimentology and tectonic settings. Blakie and Son, Glasgow, pp 313

Peteet D (1995) Global Younger Dryas? Quaternary Int 28:93-104. doi:10.1016/10406182(95)00049-O

Petit-Maire N, Riser J (1981) Holocene lake deposits and paleoenvironments in central Sahara, northeastern Mali. Palaeogeogr Palaeocl 35:45-61. doi:10.1016/00310182(81)90093-6

Rachocki AH (1981) Alluvial fans. Wiley, New York

Revel JC, Rouaud M (1985) Mécanismes et importance des remaniements dans le Terrefort toulousain (Bassin aquitain, France). Pedologie (Gent) XXXV-2:171-189

Servant M, Servant S (1983) Paleohydrology of an upper quaternary lake in Chad. In: Carmouze JP, Durand JR, Lévèque D (eds) Lake Chad. Junk, The Hague, pp 11-26 
Sheppard RA, Gude AJ (1968) Distribution and genesis of authigenic silicate minerals in tuffs of Pleistocene Lake Tecopa, Inyo County, California. U.S. Geol Surv 597:1-38

Sheppard RA, Gude AJ (1969) Diagenesis of tuffs in the Barstow Formation, Mud Hills, San Bernardino County, California. U.S. Geol Surv 830:1-35

Sheppard RA, Gude AJ (1973) Zeolites and associated authigenic silicate minerals in tuffaceous rocks of the Big Sandy Formation, Mohave County, Arizona. U.S. Geol Surv $830: 1-36$

Singer A, Stoffers P (1980) Clay mineral diagenesis in two east african lake sediments. Clay Miner 15:291-307. doi:10.1180/claymin.1980.015.3.09

Street-Perrott FA, Roberts N (1983) Fluctuations in closed-basin lakes as indicator of past atmospheric circulation patterns. In: Street-Perrott FA, Beran M, Ratcliffe R (eds) Variations in the global water budget, Dordrecht, pp 331-341

Stuiver M, Reimer PJ, Bard E, Beck JW, Burr GS, Hughen KA et al (1998) INTCAL98 Radiocarbon age calibration, 24 000-0 cal BP. Radiocarbon 40:1041-1083

Sunborg A, Janson M (1991) Hydrology of rivers and river regimes. In: Starkel L, Gregory KJ, Thornes JB (eds) Temperate Palaeohydrology. Wiley, Chichester, pp 13-29

Surdam RC, Eugster HP (1976) Mineral reactions in the sedimentary deposits of the Lake Magadi Region, Kenya. Geol Soc Am Bull 87:1739-1752. doi :10.1130/00167606(1976)87<1739:MRITSD>2.0.CO;2

Surdam RC, Parker RD (1972) Authigenic aluminosilicate minerals in the tuffaceous rocks of the Green River formation, Wyoming. Geol Soc Am Bull 83:689-700. doi:10.1130/00167606(1972)83[689:AAMITT]2.0.CO;2

Teruggi ME (1964) A new and important occurence of sedimentary analcime. J Sediment Petrol 34:761-767

Tettenhorst R, Moore GJ (1978) Stevensite oolites from the Green River Formation of central Utah. J Sediment Petrol 48:587-594

Thompson JB (2000) Microbial whitings. In: Ridings RE, Awramik SM (eds) Microbial sediments. Springer-Verlag, Berlin, pp 251-260

Thompson JB, Ferris FG, Smith DA (1997) Geomicrobiology and sedimentology of the mixolimnion and chemocline in Fayetteville Green Lake, New York. Palaios 5:52-75. doi: $10.2307 / 3514996$

Trément F, Argant J, Bréhéret JG, Cabanis M, Dousteyssier B, Fourmont A et al (2007) Un ancien lac au pied de l'oppidum de Gergovie: interactions sociétés-milieux dans le bassin versant de Sarliève à 1'Holocène. Gallia 64:289-351 
Van Lith Y, Warthmann R, Vasconcelos C, McKenzie JA (2003) Sulphate-reducing bacteria induces low-temperature Ca-dolomite and high Mg-calcite formation. Geobiology 1:71-79. doi:10.1046/j.1472-4669.2003.00003.x

Vasconcelos C, McKenzie J (1997) Microbial mediation of modern dolomite precipitation and diagenesis under anoxic conditions (lagoa Vermelha, Rio de Janeiro, Brazil). J Sediment Res 67:378-390

Vasconcelos C, McKenzie JA, Bernasconi S, Grujic D, Tien AJ (1995) Microbial mediation as a possible mechanism for natural dolomite formation at low temperatures. Nature 337:220222. doi:10.1038/377220a0

Vernet G (2005) Rapport final d'opération de diagnostic et de fouille archéologique, bassin de Sarliève, Grande Halle d'Auvergne (Cournon, Pérignat-les-Sarliève et Aubière; Puy-deDôme), 3 tomes, Inrap, Direction Inter régionale Rhône-Alpes/Auvergne, Centre archéologique régional d'Auvergne

Vernet G, Raynal JP (1995) La téphra des Roches, marqueur du volcanisme contemporain de la fin du Magdalénien dans le Massif central français. C R Geosci 321:713-720

Wright D (1999) The role of sulphate-reducing bacteria and cyanobacteria in dolomite formation in distal ephemeral lakes of the Coorong region, South Australia. Sediment Geol 126:147-157. doi:10.1016/S0037-0738(99)00037-8

Yu G, Harrison S (1995) Holocene changes in atmospheric circulation patterns as shown by changes in northern Europe. Boreas 24:260-268

Zolitschka B, Behre KE, Schneider J (2003) Human and climatic impact on the environment as derived from colluvial, fluvial and lacustrine archives-examples from the Bronze Age to the Migration period, Germany. Quat Sci Rev 22:81-100. doi:10.1016/S02773791(02)00182-8 
Figures and Tables

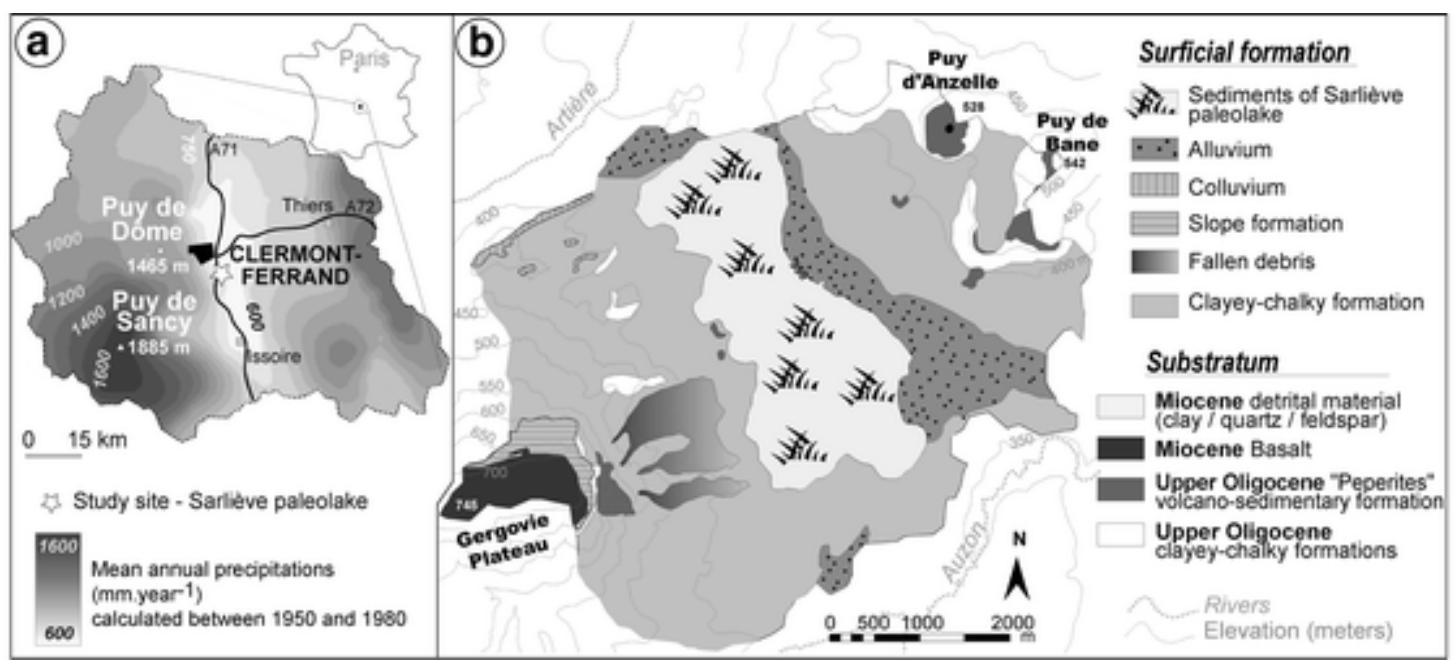

Fig. 1 Location and geological setting of Sarliève paleolake catchment. (a) Location of studied area and mean annual precipitation from Kessler and Chambraud (1986); (b) delimitation and lithological map of the Sarliève paleolake catchment from Jeambrun et al. (1973)

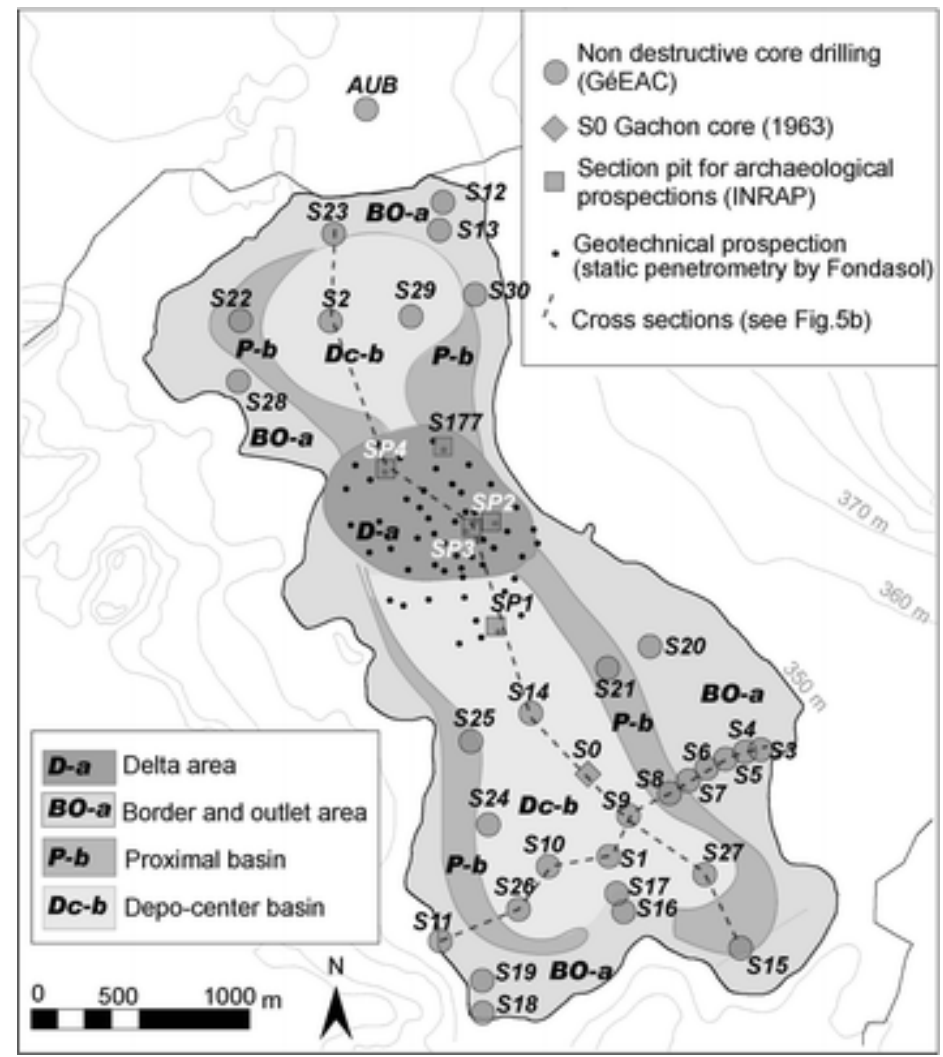

Fig. 2 Location of drillings and pits, of geotechnical surveys over the Sarliève paleolake sediments, and main lacustrine facies distribution 


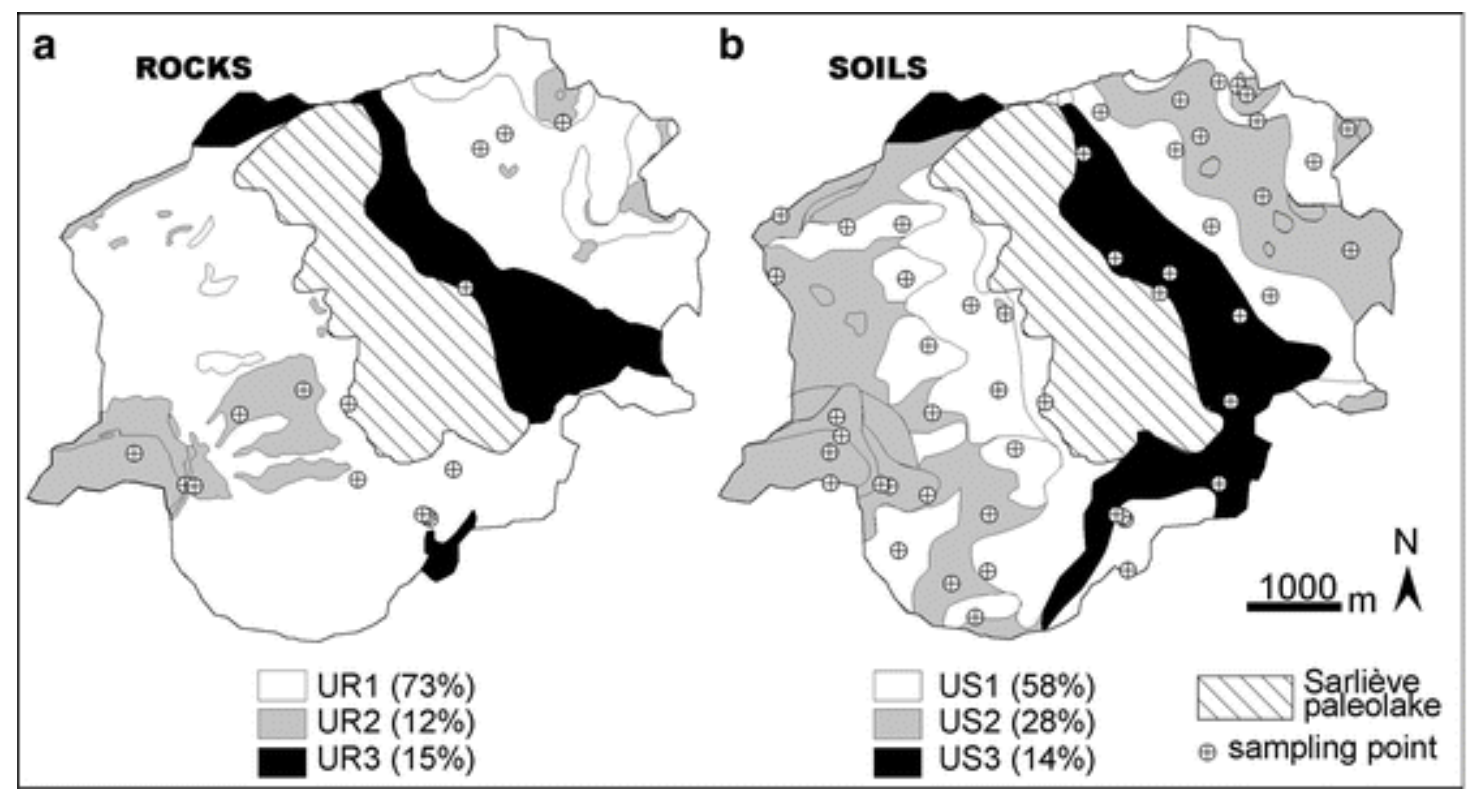

Fig. 3 Distribution of analysed rock and soil samples in the catchment on main rock and soil units, and unit surface percentage (\%). (a) Main rock units, UR1 carbonate-rich rocks, UR2 basaltic rocks, and UR3 alluvium; (b) main soil units: US1 carbonate-rich soils, US2 basaltic soils, and US3 alluvial soils

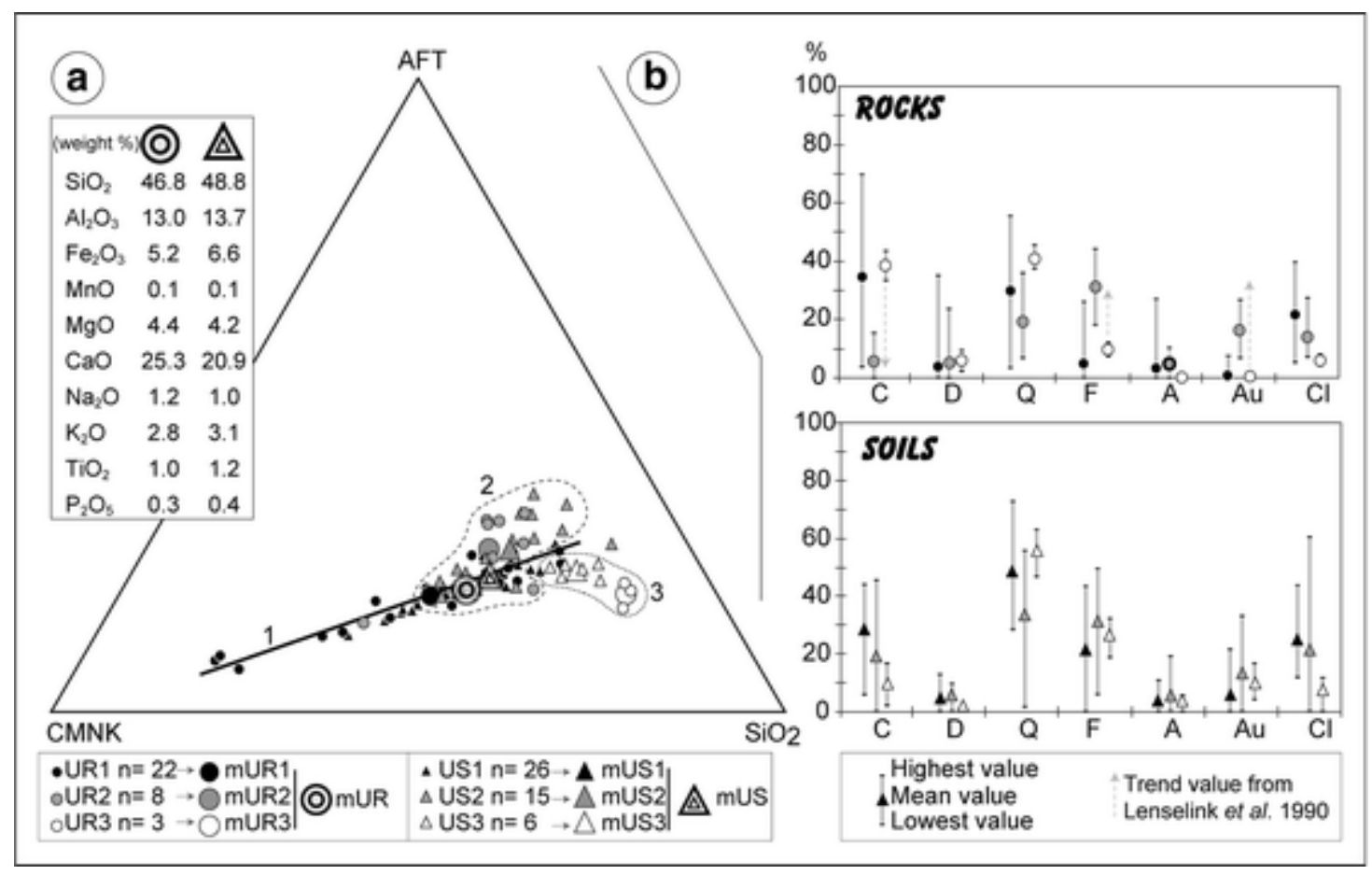

Fig. 4 Catchment lithological composition. (a) Geochemical data on CMNK

$\left(\mathrm{CaO}+\mathrm{MgO}+\mathrm{Na}_{2} \mathrm{O}+\mathrm{K}_{2} \mathrm{O}\right)-\mathrm{AFT}\left(\mathrm{Al}_{2} \mathrm{O}_{3}+\mathrm{Fe}_{2} \mathrm{O}_{3}+\mathrm{TiO}_{2}\right)-\mathrm{SiO}_{2}$ diagram. UR1, UR2, UR3: rock-unit samples; mUR1, mUR2, mUR3: mean composition of rock units; mUR: mean composition of rocks; US1, US2, US3: soil-unit samples; mUS1, mUS2, mUS3: mean composition of soil units; mUS: mean composition of soils.(b) Mineralogical composition of rock-unit (UR1, UR2, UR3) and soil-unit (US1, US2, US3) samples, in \% of the bulk; C: calcite, D: dolomite, Q: quartz, F: feldspars, A: analcite, Au: augite and Cl: clay minerals 


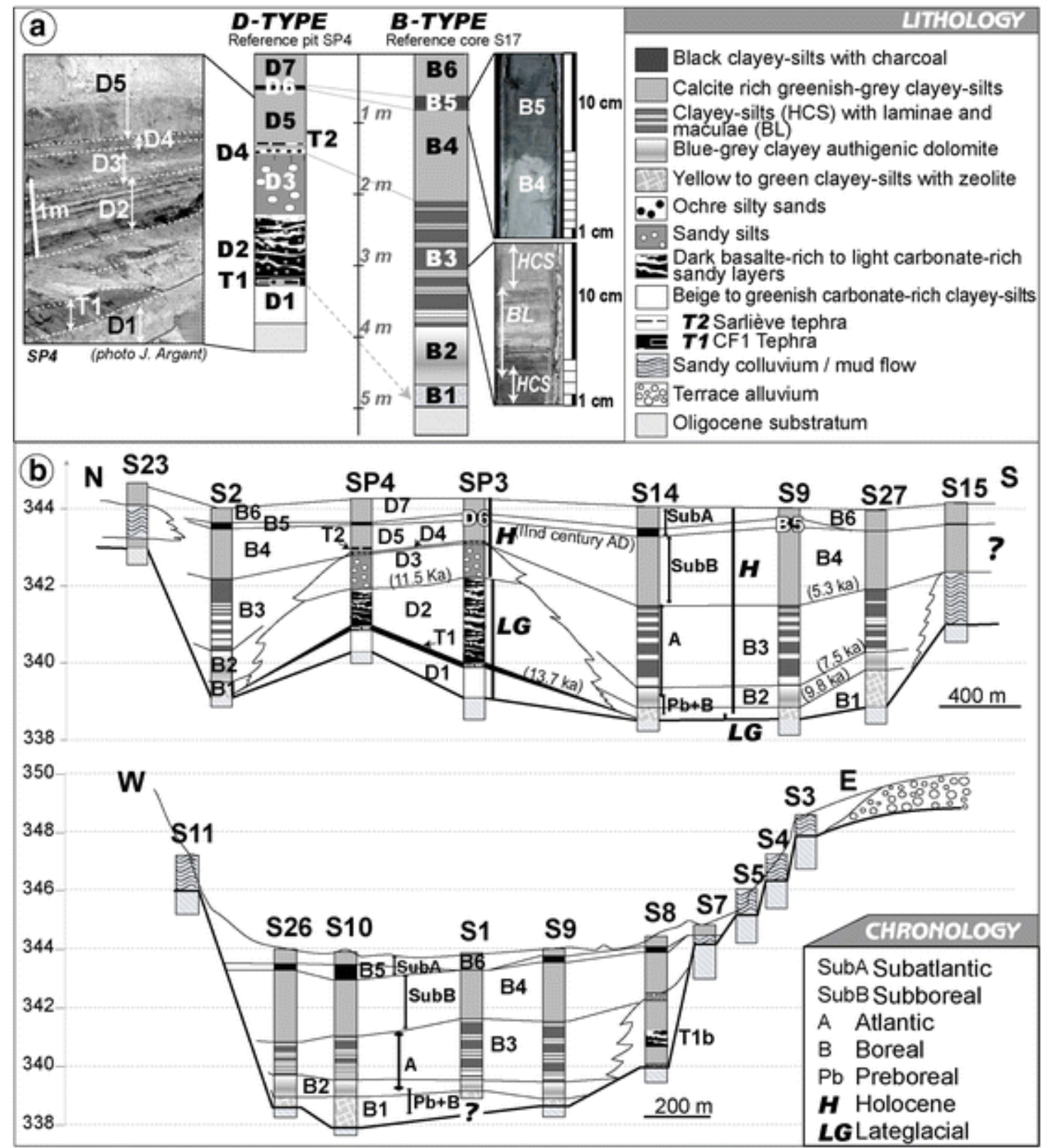

Fig. 5 Lithology of Sarliève paleolake sediments. (a) Typical delta (D-type) and basin (Btype) sediment piles and correlations; D1-D7, T1, T2, B1-B6: lithological units (see text); HCS: Homogenous Clayey-Silts; BL: Bundle of Laminae; (b) NS and WE cross-sections in Sarliève paleolake sediments from drillings; location of transects see Fig. 2; elevation data from Fondasol and Trément (personal communication) 


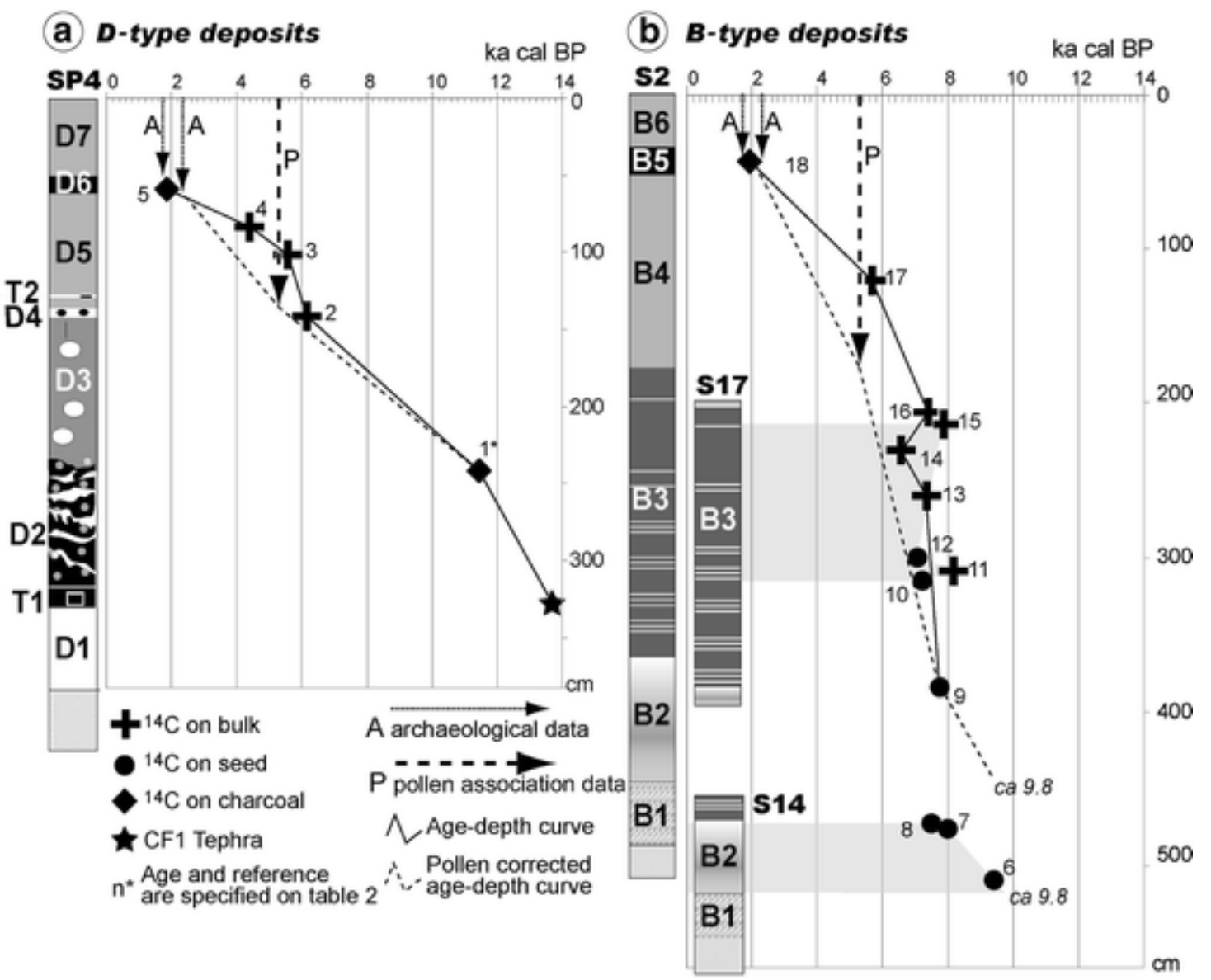

Fig. 6 Age-depth curves in both delta and basin deposits. (a) D-type deposits; (b) depocenter B-type deposits. Extending B2 age-depth curve (S14) allows age of the lower part of B2 to be estimated at ca. $9.8 \mathrm{ka}$ cal BP 


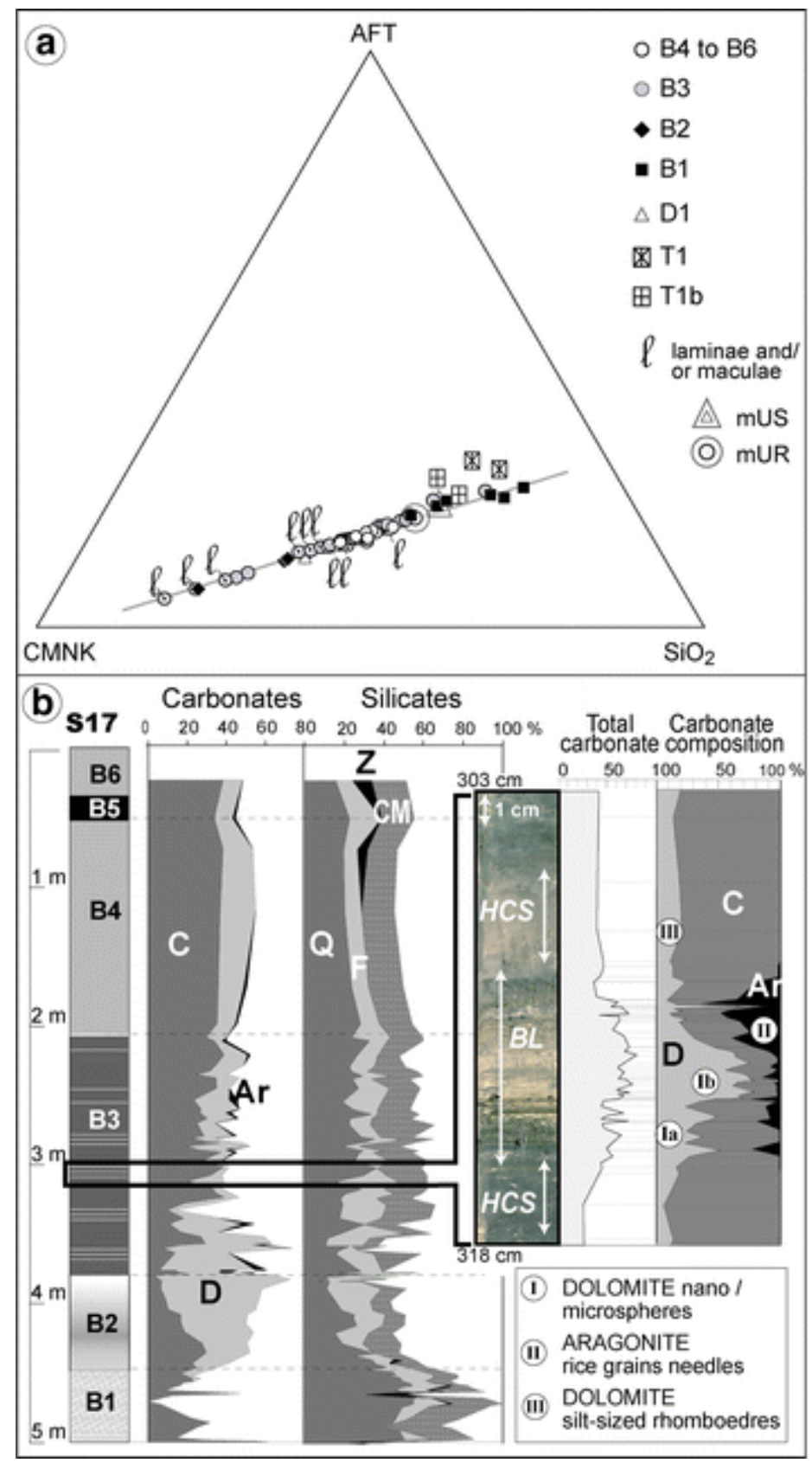

Fig. 7 Lacustrine sediment composition. (a) Geochemical composition of B1-B6, D1, T1b, T1 units and mean composition of catchment rocks (mUR) and soils (mUS) in (a) CMNK $\left(\mathrm{CaO}+\mathrm{MgO}+\mathrm{Na}_{2} \mathrm{O}+\mathrm{K}_{2} \mathrm{O}\right)-\mathrm{AFT}\left(\mathrm{Al}_{2} \mathrm{O}_{3}+\mathrm{Fe}_{2} \mathrm{O}_{3}+\mathrm{TiO}_{2}\right)-\mathrm{SiO}_{2}$ diagram; (b) total carbonate and silicate contents and composition in $\mathrm{S} 17$ core sediments (B-type sediments); details of carbonate contents, composition and habits in an $\mathrm{HCS} / \mathrm{BL} / \mathrm{HCS}$ sequence; C: calcite, Do: dolomite, Ar: aragonite, Q: quartz, F: feldspar, Z: zeolite, CM: clay minerals, HCS: Homogenous Clayey Silts, BL: Bundles of Laminae and maculae 


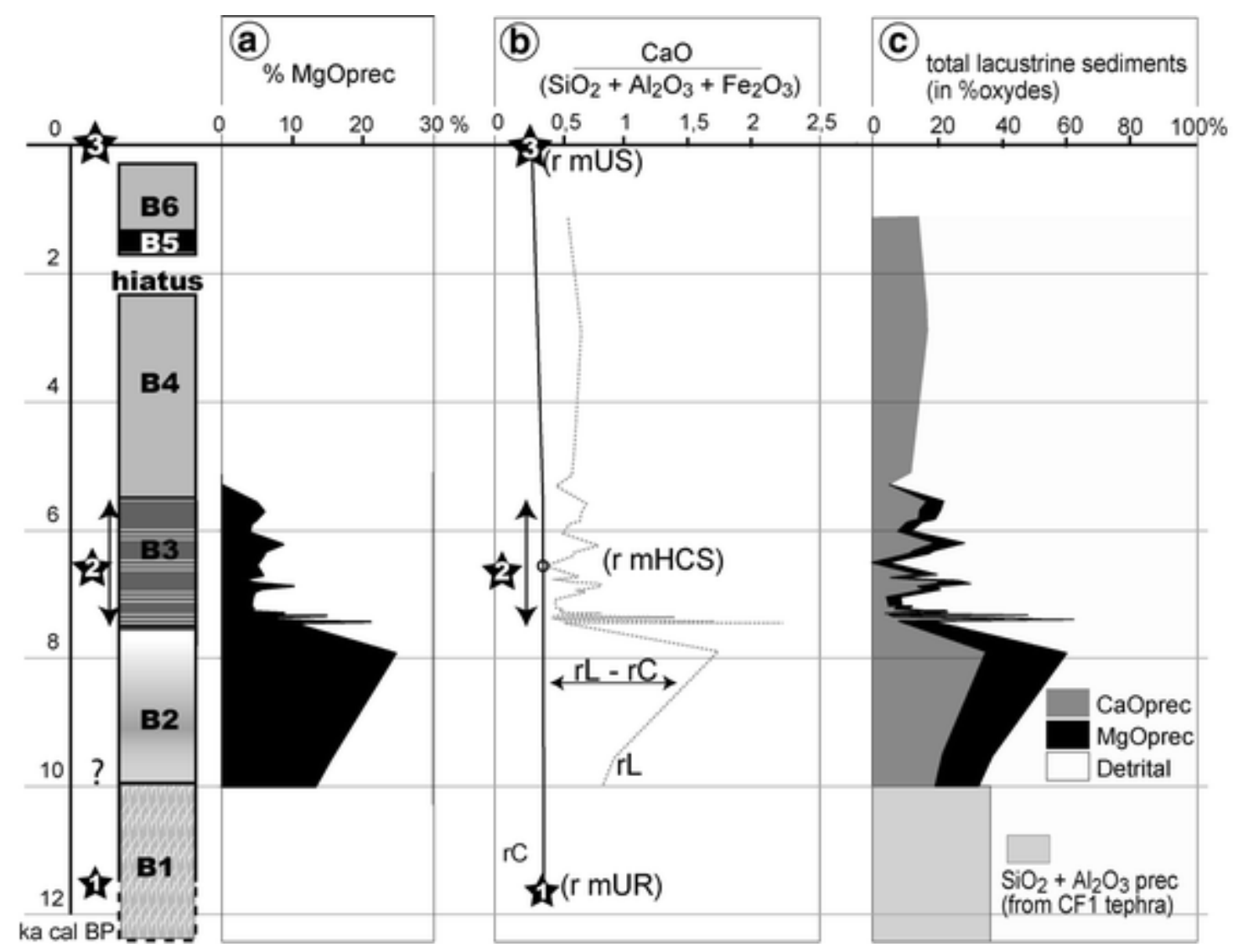

Fig. 8 Estimation of precipitated carbonates, and precipitated silicates from CF1 tephra, in Btype lacustrine sediments from S17 core; B1-B6: sediment units. (a) Precipitated $\mathrm{MgO} \%$ in sediments; (b) $\left.(\mathrm{CaO}) / \mathrm{SiO}_{2}+\mathrm{Al}_{2} \mathrm{O}_{3}+\mathrm{Fe}_{2} \mathrm{O}_{3}\right)$ ratio in catchment $(\mathrm{rC})$ (1, mUR: mean rock value; 2 , mHCS: minimal HCS layer value; 3 , mUS: mean soil value) and in lacustrine sediments (rL); (c) precipitated $\mathrm{MgO}$ and $\mathrm{CaO}$, and precipitated $\mathrm{SiO}_{2}$ and $\mathrm{Al}_{2} \mathrm{O}_{3}$ from $\mathrm{CF} 1$ tephra in $\%$ of the lacustrine bulk sediment 

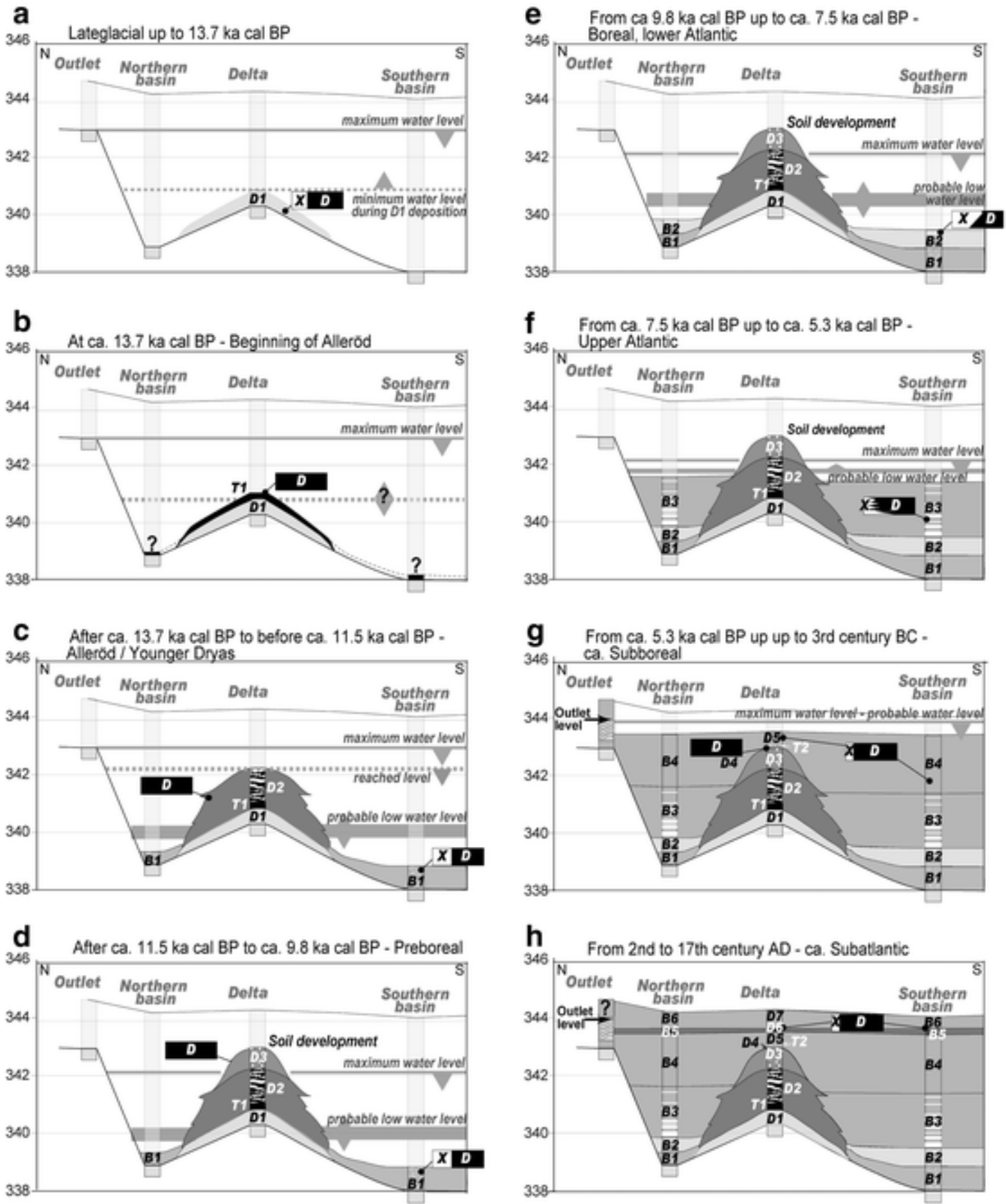

Fig. 9 Scenario of evolution of the sedimentary filling and composition of sediments (X, biochemical and D, detrital) and hydrological evolution of Sarliève lake from Late Glacial to 17 th century AD 
Table 1 Summary of lacustrine sediment facies and correlation

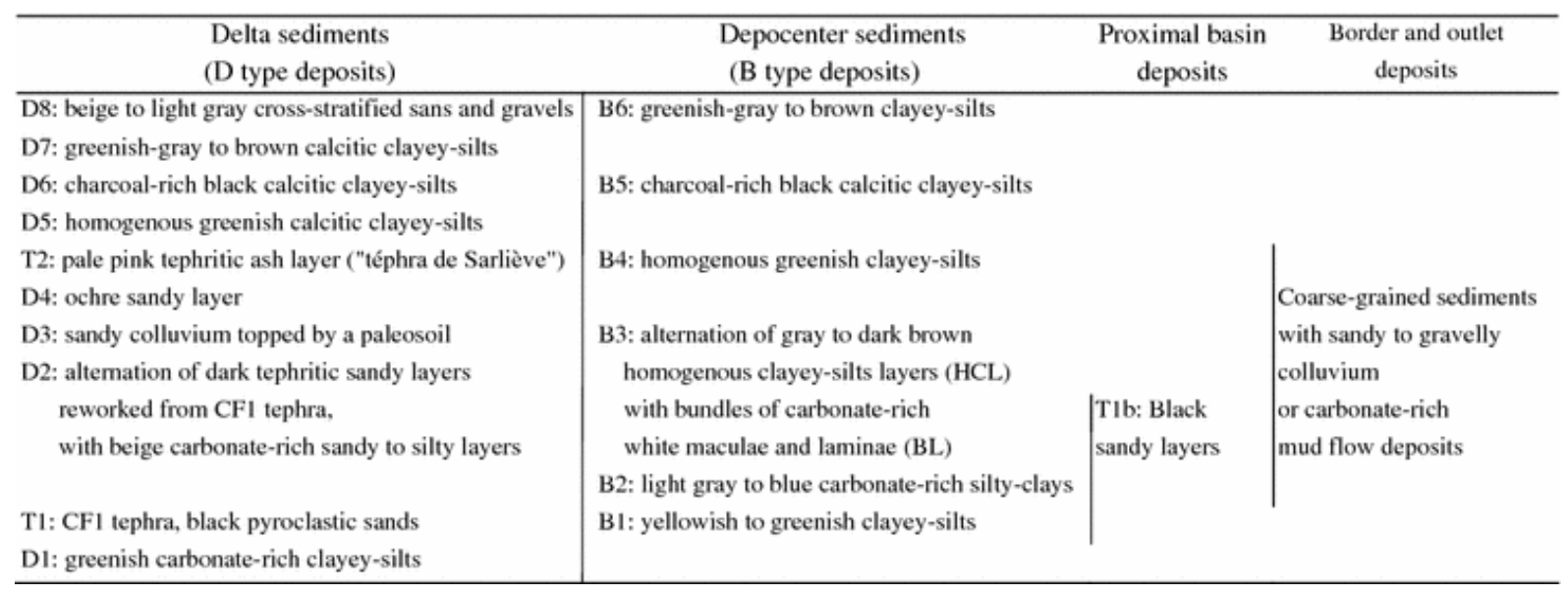


Table $2{ }^{14} \mathrm{C}$ dates on Sarliève lacustrine sediments

\begin{tabular}{|c|c|c|c|c|c|c|c|}
\hline Facies & $\begin{array}{l}\text { Sample } \\
\text { number }\end{array}$ & Unit & Material & Reference & $\begin{array}{l}{ }_{\mathrm{BP}}^{14} \mathrm{C} \text {-age } \\
\end{array}$ & $\begin{array}{l}2 \sigma \text { calibrated }{ }^{14} \mathrm{C} \text {-age } \\
\text { in } \mathrm{ka} \mathrm{BP}^{\mathrm{b}}\end{array}$ & \begin{tabular}{|l} 
See \\
Fig. 6
\end{tabular} \\
\hline \multirow{5}{*}{$\begin{array}{l}\text { D-type } \\
\text { deposits }\end{array}$} & SP4 65-69 & D5/D6 & Charcoal & $\begin{array}{l}\text { LY-2002 (GrA- } \\
22118)\end{array}$ & $1940 \pm 60$ & $1.86 \pm 0.14$ & 5 \\
\hline & SP4 79-88 & D5 & $\begin{array}{l}\text { Sediment } \\
\text { bulk }\end{array}$ & LY 2398 OxA & $3940 \pm 35$ & $4.4 \pm 0.1$ & 4 \\
\hline & SP4 99-104 & D5 & $\begin{array}{l}\text { Sediment } \\
\text { bulk }\end{array}$ & LY 2397 OxA & $4850 \pm 35$ & $5.57 \pm 0.08$ & 3 \\
\hline & SP4138-144 & D4/D5 & $\begin{array}{l}\text { Sediment } \\
\text { bulk }\end{array}$ & LY 2392 OxA & $4840 \pm 45$ & $6.15 \pm 0.3$ & 2 \\
\hline & SP4 235-250 & D2/D3 & Charcoal & LY-11362 & $9985 \pm 65$ & $11.46 \pm 0.23$ & 1 \\
\hline \multirow{13}{*}{$\begin{array}{l}\text { B-type } \\
\text { deposits }\end{array}$} & S2 $40-45$ & B4/B5 & $\begin{array}{l}\text { Sediment } \\
\text { bulk }\end{array}$ & LY-9813 & $1935 \pm 35$ & $1.93 \pm 0.07$ & 18 \\
\hline & S2 120 & B4 & $\begin{array}{l}\text { Sediment } \\
\text { bulk }\end{array}$ & $\begin{array}{l}\text { LY-1985 (GrA- } \\
21830)\end{array}$ & $4930 \pm 70$ & $5.69 \pm 0.2$ & 17 \\
\hline & S2 205 & B1 & $\begin{array}{l}\text { Sediment } \\
\text { bulk }\end{array}$ & $\begin{array}{l}\text { LY-1984 (GrA- } \\
\text { 21829) }\end{array}$ & $6480 \pm 70$ & $7.41 \pm 0.14$ & 16 \\
\hline & S2 231 & B2 & $\begin{array}{l}\text { Sediment } \\
\text { bulk }\end{array}$ & $\begin{array}{l}\text { LY-1983 (GrA- } \\
\text { 21827) }\end{array}$ & $5770 \pm 70$ & $6.57 \pm 0.16$ & 14 \\
\hline & S2 260 & B3 & $\begin{array}{l}\text { Sediment } \\
\text { bulk }\end{array}$ & $\begin{array}{l}\text { LY-1982 (GrA- } \\
\text { 22023) }\end{array}$ & $6390 \pm 50$ & $7.34 \pm 0.09$ & 13 \\
\hline & S2 384 & B2 & Seed & $\begin{array}{l}\text { LY-1981(GrA- } \\
21826)\end{array}$ & $6890 \pm 80$ & $7.76 \pm 0.17$ & 9 \\
\hline & S17 213-215 & B3 & $\begin{array}{l}\text { Sediment } \\
\text { bulk }\end{array}$ & LY-2436 (GrA) & $7060 \pm 50$ & $7.86 \pm 0.1$ & 15 \\
\hline & S17 299-300 & B3 & Seed & LY-2437 (GrA) & $6200 \pm 50$ & $7.1 \pm 0.15$ & 12 \\
\hline & S17 308-309 & B3 & $\begin{array}{l}\text { Sediment } \\
\text { bulk }\end{array}$ & LY-2438 (GrA) & $7420 \pm 50$ & $8.21 \pm 0.14$ & 11 \\
\hline & S17 314-315 & B3 & Seed & LY-2439 (GrA) & $6330 \pm 50$ & $7.26 \pm 0.16$ & 10 \\
\hline & S14 470,75 & B2/B3 & Seed & LY-2433 (GrA) & $6640 \pm 70$ & $7.52 \pm 0.44$ & 8 \\
\hline & S14 474-475 & B2 & Seed & LY-2434 (GrA) & $7180 \pm 50$ & $8.01 \pm 0.14$ & 7 \\
\hline & S14 506-510 & B2 & Seed & LY-2435 (GrA) & $8450 \pm 70$ & $9.42 \pm 0.12$ & 6 \\
\hline
\end{tabular}

${ }^{a}$ SP4 Core number, 65-69 depth in $\mathrm{cm}$

${ }^{\mathrm{b}}$ According to INTCAL 98 calibration curve (Stuiver et al. 1998) 